\title{
Dietary Possibilities to Mitigate Rumen Methane and Ammonia Production
}

\author{
Małgorzata Szumacher-Strabel and Adam Cieślak \\ Poznań University of Life Sciences, \\ Department of Animal Nutrition and Feed Management, \\ RUMEN PULS \\ Poznań \\ Poland
}

\section{Introduction}

Efficiency of ruminal metabolism is a significant factor affecting production and release of pollutants, i.e. methane and ammonia. Efficient and balanced ruminal fermentation reduces the emission of gases, particularly methane, to the atmosphere. Losses of energy from the feed ration, connected with the production of methane, are particularly significant in ruminants, since approx. $2 / 3$ production costs are generated by feeds (including forages), fed to animals. Actions aiming at a limitation of methanogenesis in ruminants, at the simultaneous monitoring of quantitative and qualitative changes in methanogens, are justified from the scientific and economic point of view. Proposals of legislative changes include the intention expressed by the European Commission to introduce the so-called cow tax, a tax on kept ruminants.

Constant temperature on Earth is maintained thanks to a certain type of the greenhouse effect. Solar radiation with a wavelength of $0.1-4 \mu \mathrm{m}$, reaching the Earth's surface, results in its natural heating, causing the emission of thermal radiation with a wavelength of 4 to 80 $\mu \mathrm{m}$. Greenhouse gases (GHG) are found in the atmosphere and absorb radiation with an identical wavelength, at the same time causing an elevation of temperature in the lower layers of the atmosphere (IPCC, 2007). Thanks to the above, the mean temperature of the troposphere is by $33^{\circ} \mathrm{C}$ higher than in case of the absence of an atmosphere, facilitating the development and preservation of life forms on Earth (IPCC, 2007). However, it is estimated that excessive emission of greenhouse gases, caused by human activity, in the last century resulted in the global temperature increasing by $0.5^{\circ} \mathrm{C}$. In view of the above the Intergovernmental Panel on Climate Change (IPCC) forecasts that by the year 2100 the temperature on Earth will increase by $1.8-3.9^{\circ} \mathrm{C}$. This may lead to the melting of ice caps in the Arctic and Antarctic, elevation of sea and ocean levels, continentality of climates, elongation or shortening of the vegetation seasons depending on the latitude, disturbances in air circulation in the atmosphere. Moreover, the above mentioned changes may contribute e.g. to the intensification of tropical cyclones and such phenomena as El Niño or the Quasi-Biennial Oscillation (QBO; Topping, 2007). 
The most important greenhouse gases, affecting the above mentioned climatic changes, include carbon (IV) oxide, methane and nitrogen (I) oxide (Steinfeld et al. 2006). Since other greenhouse gases are converted into carbon dioxide equivalents, public attention is focused on this gas. However, it needs to be stressed that $\mathrm{CH}_{4}$ and $\mathrm{N}_{2} \mathrm{O}$ have much higher global warming potentials (GWP) in comparison to $\mathrm{CO}_{2}$, i.e. 23 and 296, respectively (Paustian et al., 2006, Steinfeld et al., 2006). GWP is an index presenting quantitatively the effect of individual substances on the greenhouse effect, referred to $\mathrm{CO}_{2}(\mathrm{GWP}=1)$ in the assumed time horizon, typically 100 years. The concentration of GHG within the last several years has changed drastically. It is estimated that since 1750 the concentration of methane in the atmosphere increased by $1060 \mathrm{ppm}$, which amounts to $151 \%$. As a result of human activity, which for decades has been aiming at the development of industry and agriculture, the consequences of global warming have been manifested with increasing intensity, caused e.g. by excessive emission of greenhouse gases to the atmosphere. In the opinion of some authors the primary sources of methane emission may be divided into natural (accounting for 29\%) and anthropogenic (71\%; Wuebbles \& Hayboe, 2002). Thus the effect of anthropogenic factors on climate change is much greater than that of natural factors, such as volcanic eruptions or solar bursts.

Among anthropogenic factors agriculture, including animal production, is a major sector with a highly significant contribution to environmental pollution, as it has been increasing with an increase in the human population worldwide.

Agriculture is considered to be responsible for about two-thirds of the anthropogenic sources and among them enteric microbial fermentation in ruminants is the main producer of methane and other greenhouse gasses, as well as ammonia. According to the Report of the Food and Agriculture Organization FAOSTAT (FAO, 2008) approx. 56 billion animals are kept worldwide as slaughter animals, while according to some data a 2-fold increase in the population is forecasted by 2050 (Steinfeld et al., 2006). It was shown that greenhouse emission is connected with the population of farm animals (USDA, 2011). Methane produced by ruminants contributes to $95 \%$ of the anthropogenic total methane and $18 \%$ of the total greenhouse gasses in the atmosphere. Production and emission of greenhouse gases from ruminants is strongly correlated with rumen energy and protein metabolism, as well as changes occurring in manure. According to Steinfeld et al. (2006) 86 million ton methane are released annually to the atmosphere from animal production. Of that pool as much as 95 to $97 \%$ originate from ruminants, including 63 to $64 \%$ produced by cattle, 9 to $10 \%$ buffaloes, $8 \%$ sheep, while 3.8 to $3.9 \%$ by goats (Johnson \& Ward, 1996). The other 3 to $5 \%$ are produced by monogastric animals (Crutzen et al., 1986). Methane in ruminants is formed as a result of ruminal and intestinal fermentation, of which $90 \%$ of this amount comes from the rumen (Khalil, 2000).

The energy necessary for the ruminants is derived mostly from plant polysaccharides such as cellulose, whereas nitrogen originates from ruminal ammonia and amino acids. As a result of ineffective carbohydrate and protein digestion in the rumen, methane and ammonia are formed. Production of methane during fermentation of feeds in the rumen is connected with the loss of crude energy from the consumed feed ration. Thus limitation of these losses, resulting from the process of methane formation, is becoming increasingly important both in view of environmental protection and the economic aspect. 
The international community, perceiving the need to counteract the negative effects of greenhouse gases, organized in 1992 in Rio de Janeiro the UN Conference on the Environment and Development. During the conference assumptions were developed for international cooperation to reduce greenhouse emissions responsible for the phenomenon of global warming. However, to date the Kyoto protocol of 1997, which entered into force on 16 February 2005 and which has been approved by 174 countries, is the most important document introducing limits to gas emissions. On the power of the resolutions of this Protocol the countries, which decided to ratify it, declared to reduce by the year 2012 their emissions by negotiated amounts listed in the appendix to the protocol (at least $5 \%$ of the emission level from 1990 - art. 3 item 1) for carbon dioxide, methane, nitrogen oxide, HFC and PFC, i.e. greenhouse gases. In case of the lower or excessive emissions of these gases, signatories of the agreement declared to engage in the trade exchange consisting in the sale or purchase of quotas from other countries. If the Kyoto protocol is fully implemented, it is forecasted that as a result of its resolutions the mean global temperature is going to be reduced by $0.02^{\circ} \mathrm{C}$ to $0.28^{\circ} \mathrm{C}$ by 2050 . Moreover, Poland was a participant of the Earth Summit in Rio de Janeiro in 1992 and one of the countries, which approved the Framework UN Convention on Climate Change, thanks to which it could sign the Kyoto Protocol. In comparison to the level from 1988, i.e. the basal year for former COMECON countries, Poland is to reduce its emission by $6 \%$. Out of the total amount of 350 million ton methane emitted annually to the atmosphere, approx. 80 million ton is generated by animal production, which constitutes as much as $23 \%$ of the methane pool resulting from human activity (Islam \& Begum, 1997).

Actions aiming at a reduction of the amount of methane produced by ruminants are of interests for researchers worldwide. However, methods to limit production and emissions have to be adapted to local conditions, i.e. the feed base in each of the countries, etc. Also the scientific community systematically organizes conferences on methane emission from the agricultural sector. The first such conference was organized in Japan in 2001, with 200 delegates from 20 countries, while as many as 400 delegates from 36 countries participated in the latest one held in 2010 in Canada.

Moreover, the European Union and many other countries see the necessity to introduce common fees for emitted methane, at similar principles as those for the already implemented fees for $\mathrm{CO}_{2}$ emissions. Low profitability of agricultural production and the relatively low investment potential - as a result of considerable fragmentation - suggests that taxation of $\mathrm{CH}_{4}$ emission will result in a situation when agriculture, primarily animal breeding, will suffer most from these additionally financial burdens. One of the current proposal assumes fees of $€ 5$ for 1 ton of emitted gas, which implies a fee proposals of $€ 13$ per dairy cow, $€ 7$ per head of non-dairy cattle and $€ 1$ per 1 sheep. This constitutes an integral part of the adopted strategy recorded in the so-called Kyoto protocol. These resolutions constitute a supplement to the United Nations Framework Convention on Climate Change, and at the same time they are an international agreement concerning counteractions to global warming.

\section{Rumen metabolism - Microorganisms involved in hydrogen and nitrogen metabolism}

Microorganisms colonizing the rumen participate in the digestion of basic nutrients. Particularly thanks to the presence of bacteria all changes in the fermentation processes are made possible. Rumen bacteria are capable of producing specific enzymes participating in the digestion process. In case of ruminants bacterial enzymes are very important, since these 
animals are not able to synthesize their own digestive enzymes in their forestomachs. Depending on the type of microorganisms, their interrelations and efficiency, they influence metabolic changes in animals.

In ruminants, such as domestic cattle, sheep and goats, the main fermentation processes of nutrients in the consumed feed ration occur in the first forestomach, i.e. the rumen. These processes to a most part are possible thanks to the microorganisms colonizing it. The microbial population in the rumen consists of bacteria at $10^{10}$ cells $/ \mathrm{ml}$, protozoans at $10^{6}$ cells $/ \mathrm{ml}$, fungi at $10^{3}-10^{7}$ cells $/ \mathrm{ml}$ and methanogens at $10^{9}$ cells $/ \mathrm{ml}$ (Kamra, 2005). However, it needs to be remembered that according to some data so far only approx. $10 \%$ microbial population have been identified in the ruminal ecosystem (Pers-Kamczyc et al., 2011). Most microorganisms participating in the production of methane for their adequate growth and development require the following environmental conditions: $\mathrm{pH}$ between 6 and 8 (Jones et al., 1987) and redox potential at $-300 \mathrm{mV}$ (Stewart \& Bryant, 1988).

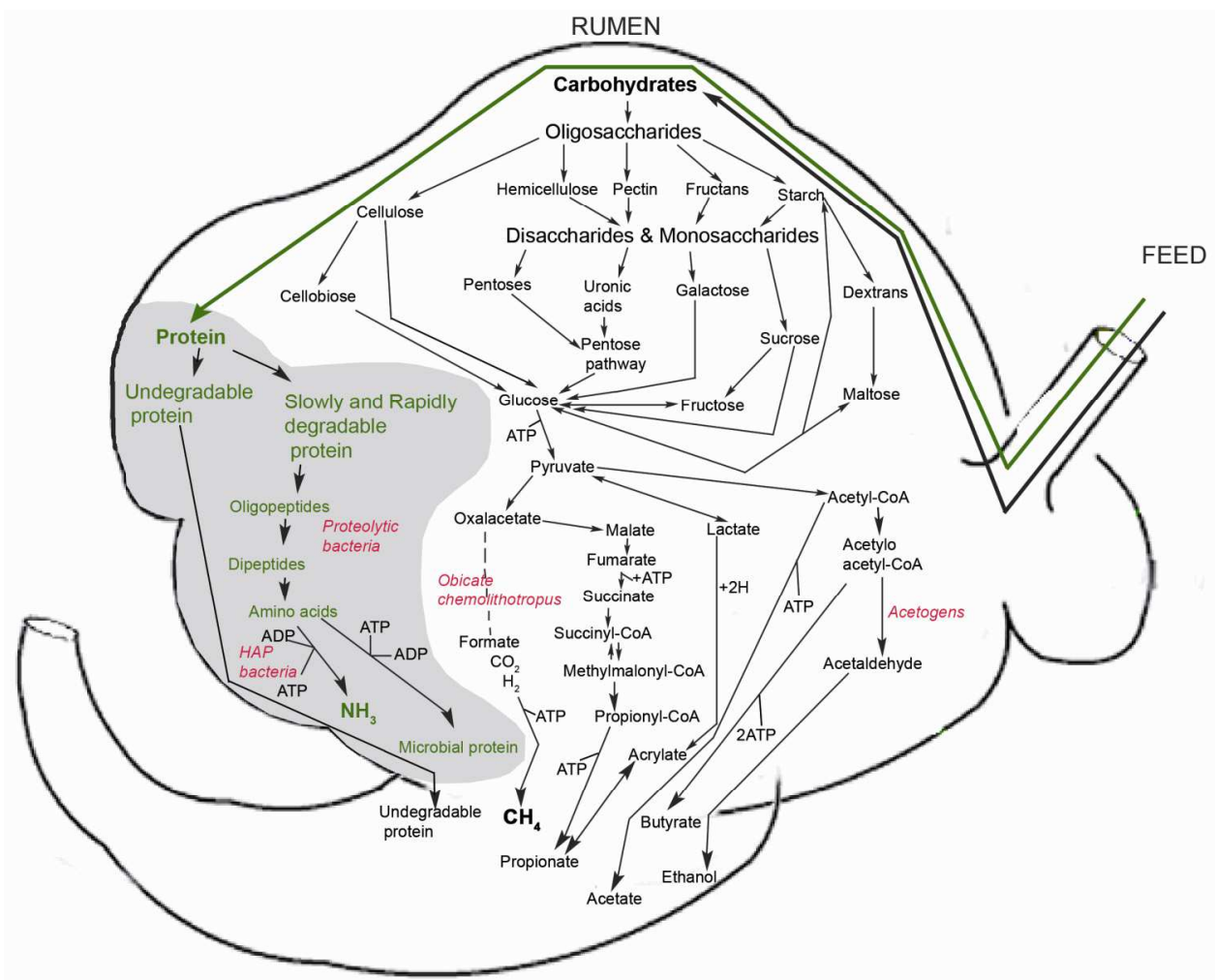

Fig. 1. A schematic pathways of carbohydrates and protein rumen fermentation (Van Soest, 1994 with modifications)

\subsection{Rumen methanogens}

Methanogens are microorganisms, which are directly responsible for the formation of methane in this ecosystem. They belong to the group of Archaea within the kingdom of 
Euryarcheota. Archaea differ fundamentally from bacteria belonging to the group of eubacteria both in terms of their structural traits and metabolism. Murein, a peptidoglycan characteristic of the cell wall, in case of Archaea, is replaced by pseudomurein (Cheong et al., 1991). Due to that fact Archaea is not sensitive to antibiotics inhibiting the synthesis of the cell walls, such as valinomycin, penicillin or cycloserine (Hilpert et al., 1981). Moreover, in contrast to the bacterial wall composed of glycerol esters and fatty acids, the bilayer lipid wall of Archaea consists of di- or tetra-esters of glycerol and isoprenoid chains (Hafenbrandl et al., 1996). Such a structure of the cell wall, among other things, facilitates the growth and development of these microorganisms under extreme conditions such as e.g. protozoan cells. Another trait differentiating methanogens from eubacteria is related with the base sequence in the ribosomal RNA (Stewart et al., 1997). Only in methanogens the occurrence of the following was detected: deazariboflavin derivative of $F_{420}$, methanopterin, methanofuran, nickel tetrapyrol factor $\mathrm{F}_{430}$ and coenzyme $\mathrm{M}$. These enzymes and their prosthetic groups are required for the transformation of $\mathrm{H}_{2}$ and $\mathrm{CO}_{2}$ to methane. Also vitamin $B_{12}$ is necessary for the appropriate course of this process.

McAlister et al. (1996) described 5 species of methanogens living in the rumen from among 66 found in nature. According to Stewart et al. (1997) the most important species include Methanobacterium formicicum, Methanobrevibacter ruminantium, Methanosaricina barkeri, Methanosaricina mazei and Methanomicrobium mobile. Methanogenesis may occur only under anaerobic conditions at the participation of methanogens using hydrogen, being a byproduct of metabolism in the other groups of microorganisms. Methanogens belong to the biggest population of microorganisms using hydrogen formed in metabolic processes in the alimentary tract of ruminants. Concentration of hydrogen ions in the ruminal environment affects the efficiency of methane production due to the loss of $\mathrm{H}+$ binding capacity by Archaea at $\mathrm{pH}$ 5.5, thus leading to further acidification (Van Kessel \& Russel, 1995). As a consequence, the population of methanogens is reduced (Russel et al., 1988). The process of methanogenesis serves essential functions in the appropriate functioning of the ruminal ecosystem, maintaining the concentration of hydrogen ions at $10^{-6}-10^{-7} \mathrm{~mol} / \mathrm{dm}^{3}$, which has an advantageous effect on carbohydrate metabolism in the rumen (Wolin \& Miller, 1988; Ushida \& Jouany, 1996). According to Morvan et al. (1996), growth and development in Achaea is correlated with the population of microorganisms degrading cellulose, leading to an increase in the concentration of hydrogen ions (the substrate to the process of methanogenesis), being a by-product in the hydrolysis of crude fiber. A synthropy was shown between bacteria and methanogens in the rumen in in vitro cultures (Wolin et al., 1997), consisting in the dependence resulting from metabolism of the analyzed group of microorganisms. Bacteria provide the substrate for methanogenesis in the form of hydrogen and formate, while methanogens reduce the concentration of products of bacterial metabolism (e.g. in the process of horizontal hydrogen transfer). These products in high amounts may be harmful for other microorganisms living in the ruminal environment. Methanogens utilize carbon dioxide for hydrogen reduction and the generated energy is used for ATP production. Thus methanogens use methane formation as the sole energygenerating mechanism. Methane formation facilitates the maintenance of a low hydrogen concentration in the rumen and improves carbohydrate metabolism (Wolin \& Miller, 1988; Ushida \& Jouany, 1996). It has been estimated that the amount of $\mathrm{H}_{2}$ used daily by a cow in the process of methanogenesis is approximately $800 \mathrm{~L}$. However, none of the carbohydratefermenting bacteria and protozoa produce methane, but many of them synthesize substrates to be transformed into methane. 


\subsection{Rumen protozoa}

Protozoans are another group of microorganisms participating in the process of methanogenesis. Similarly, as in the case of bacteria, the degradation of crude fiber being the effect of protozoan activity results in an increased concentration of hydrogen in the ruminal environment, which is used in the so-called horizontal hydrogen transfer by methanogens to the reduction of carbon (IV) oxide. Vogels et al. (1980) and Lloyd et al. (1996) showed that cells of ciliates may be colonized by Archaea. This indicates that the population of methanogens is connected with the numbers of protozoans. According to Stewart et al. (1997) the most important species of methanogens living in symbiosis with protozoans include Methanobacterium formicicum, Methanobrevibacter ruminantium, Methanosaricina barkeri, Methanosaricina mazei and Methanomicrobium mobile. However, it needs to be remembered that due to a different structure of cell surface in protozoan cells species preferences may occur in methanogens (Vogels et al., 1980). This seems to be confirmed by studies conducted by Regensbogenova et al. (2004a), which showed that Methanomicrobium mobile is found mainly in single-species cultures of Metadinium medium, Entodinium furca monolobum and Diplodinium dentatum. In turn, Kamra (2005) reported 4 other ruminal ciliate species from the group of Entodiniomorpha, which remain in close symbiosis with methanogens, i.e. Entodinium elonginucleatum, Entodinium bursa, Eudiplodinium maggii and Eremoplastron bovis. In other studies it was shown that the symbiosis of protozoans and methanogens may be observed in the ruminal ecosystem in case of Dasytricha ruminantium, Entodinium caudatum, Entodinium furca monolobum, Diplodinium dentatum, Eremoplastron dilobum, Metadinium medium, Epidinium ecaudatum and Ophyroscolex caudatus (Finlay et al., 1994; Kisidayova et al., 2000; Regensbogenova et al., 2004b; Cieślak et al., 2006a). Literature data seem to be ambiguous e.g. due to such factors as latitude, at which a given study was conducted, the applied feed ration or the species of animals. According to some studies (Vogels et al., 1980) methanogens may be both ecto- and endo-symbionts of protozoans. Thus, by reducing the population of protozoans we also reduce the population of Archaea, leading to a decreased methane emission (Ushida \& Jouany, 1996; Dohme et al., 2001; Machmúller et al., 2003; Soliva et al., 2003; Hu et al., 2005; Cieślak et al., 2006b; Goel et al., 2008; Karnati et al., 2009). Cieślak et al. (2009a) found different metabolic responses in case of rumen ciliates Entodinium caudatum and Diploplastron affine and their associated bacteria. In addition, the same group of authors stated that the rumen protozoa may produce different levels of methane, that is correlated with population size. For example, the Epidinium ecaudatum monoculture was characterized by the lowest cell population ( 386 cells per ml) producing $0.77 \mathrm{mmol}$ methane, whereas Entodinium caudatum with the highest cell population (6183 cells per $\mathrm{ml}$ ) was the lowest methane producer ( $0.54 \mathrm{mmol}$; Cieślak et al., unpublished).

\subsection{Rumen fungi}

Another example of horizontal hydrogen transfer is provided by the symbiosis between fungi and methanogens. According to Joblin et al. (2002), the primary products of metabolism in Fungi imperfecta, such as hydrogen, carbon (IV) oxide or formate, similarly as in case of the previously mentioned microorganisms, may be used by methanogens in the process of methanogenesis. It was shown that in fungal monocultures, concentrations of metabolic products, i.e. formate, hydrogen, lactate and methanol, were drastically reduced, while the amount of acetate was increasing (Joblin et al. 2002). Moreover, in other studies, it was shown that in the culture of fungi with methanogens cellulolytic and xylanolytic 
activity of eucaryota was much higher than in case of pure cultures (Williams et al., 1995). In turn, according to Nakashimada et al. (2000) incubation of Neocallimastix frontalis and methanogens leads directly to the transformation of cellulose into methane.

\subsection{Rumen bacteria}

When analyzing the process of methanogenesis occurring in the rumen in terms of the participating microorganisms we need to take into consideration the fact that this environment is a highly dynamic ecosystem, still not completely clarified by researchers even when using state-of-the-art techniques of microorganism identification (Pers-Kamczyc et al., 2011). The final composition of the biocenosis in the rumen ecosystem is the effect of various factors, e.g. diet, feed additives, health, species, age and condition of the animal, season, or geographical conditions (Stewart et al., 1997; Graeme et al., 1998; Wright et al., 2007; Cieślak et al., 2009a; Szumacher-Strabel et al., 2009a).

Enteric fermentation of livestock, mainly in ruminants, is responsible also for ammonia emission that represents the loss of dietary nitrogen and is the reason of environmental pollution. In spite of the fact that ruminants can utilize almost all nitrogen sources, the limits of the ability of dairy animals and other high producing animals to recycle $\mathrm{N}$ are rarely reached in commercial herds and excess of dietary protein leads to ammonia formation (Place \& Mitloehner, 2010). The process of ammonia formation in the rumen involves mostly proteolytic bacteria, including the hyper ammonia producing bacteria. Ineffective retention of nitrogen leads in turn to the excretion of nitrogen-rich wastes. Proteolytic bacteria as well as hyper ammonia producing bacteria (HAP) indicate a potential action in degrading protein and producing ammonia in ruminants. Although HAP are not abundant, they are characterized by high activity. According to literature data they are responsible for the degradation of protein in the rumen and thus for the amount of $50 \%$ ammonia production (Hart et al., 2008). A total of 14 morphologically differing species have been identified. The highest activity is attributed to Clostridium sticklandii, Clostridium aminophilum and Bacteroides ruminicola. They are gram-positive bacteria, sensitive e.g. to ionophore antibiotics. For the first time hyper-ammonia producing bacteria were isolated in New Zealand and Australia in sheep, cows and deer fed green forage (Attwood et al., 1995). The presence of these bacteria in the rumen fluid depends on the type of feed ration, as well as latitude at which animals live. Moreover, the group of bacteria exhibiting under specific conditions, similar properties include universal Megasphaera elsdenii and Butyrivibrio fibrisolvens, bacteria participating e.g. in the process of biohydrogenation of unsaturated fatty acids. As a result of their action excessive degradation of protein from the feed ration takes place. An addition of investigated additives to the feed ration may inhibit the development of the above mentioned bacterial species. Limitation of protein degradation in the rumen by a reduction of the population and activity of HAP is of paramount practical economic importance, since protein is one of the most expensive nutrients and an appropriate management of nitrogen in the rumen determines the productivity of animals. Limitation of protein losses and ammonia production will also contribute to a reduction of environmental pollution.

Changes in the fermentation profile of nitrogen compounds, i.e. metabolism of crude protein, are to a considerable degree dependent on the requirement of microorganisms colonizing the rumen as well as the ruminant itself. Changes of crude protein in the rumen occur in two directions. On the one hand, they are reactions of synthesis of protein in microorganisms, where non-protein compounds, such as e.g. urea, or feed protein are 
substrates for these biochemical changes. On the other hand, a reaction of degradation of feed protein, which is rich in exogenous amino acids, valuable for the intermediary metabolism of the ruminant. Unfortunately, rumen bacteria degrading feed protein reduce the amount of exogenous amino acids available to the host. Thus in order to supply an adequate level of protein and in this way important amino acids in the gastric contents its degradation by microorganisms needs to be partly reduced, thus enhancing its availability in the small intestine. Protein, transferred to the duodenum, is digested by proteolytic enzymes and is utilized by them (Kamra, 2005).

\section{Effect of feeding strategies on methane and ammonia production}

\subsection{Dietary carbohydrates}

\subsubsection{Type of feed}

The most promising approach is connected with the modulation of rumen microbial populations by proper dietary formulation. Feeding of ruminants with feeds of high nutritive value increases nutrient concentration in the feed ration, thus resulting in the increased dry matter digestibility, degradable in the rumen as well as farther sections of the digestive tract. This causes a reduced emission of $\mathrm{CH}_{4}$ per $1 \mathrm{~kg}$ DMD (dry matter digestibility) (Hegarty, 1999a). This effect may be obtained, e.g. using silage from high quality maize, which constitutes the main component of the daily feed ration used in the feeding of ruminants. Appropriate preparation of silages considerably improves nutrient availability, thus limiting the amount of produced methane per $1 \mathrm{~kg}$ milk (Moss et al., 2000; Cieślak et al., 2005). Use of higher quality feeds also causes an increase in the ad-lib consumption of dry matter from feed, thus increasing the total nutrient uptake by animals. Among other things it influences an improved milk yield of cows. However, in such a case increased production is not accompanied by a proportional increase in methane emission. This was confirmed by a study of Kirchgessner et al. (1995) indicating that a two-fold increase in milk yield (from 50001 to 10 0001 annually) results in an increase in the production of methane by only $5 \%$. Thus the total amount of methane produced by ruminants may be reduced by a decrease in the population size of dairy cattle at an increase in their productivity.

\subsubsection{Type of carbohydrates}

It was shown that the composition of the feed ration may be a factor strongly limiting the production of methane, which is directly connected with the type of carbohydrates applied in the feed ration (Moss et al. 2000). It is estimated that $1 \mathrm{~kg}$ of crude fiber gives $79 \mathrm{~g}$ of methane, whereas $1 \mathrm{~kg}$ of starch about $10 \mathrm{~g} \mathrm{CH}_{4}$ (Cieślak et al., 2005). In general, soluble carbohydrates reduce methanogenesis when compared to fiber fermentation. On the other hand, the feed ration for cows with the predominant proportion of structural carbohydrates causes an increase in the rate of methanogenesis (Moss et al., 2000). Our research also proved that methane production reached a higher level in the full forage diet, while it was lower in mixed forage-concentrate diets, and the lowest values were recorded in the mixed concentrate-forage diet (Jalč et al., 2006a, b).

\subsubsection{Structural carbohydrates}

For example, the control diet consisting of fresh alfalfa was characterized by the highest methane production $\left(9.77 \mathrm{mMd}^{-1}\right)$ when compared with the control diets rich in concentrates 
(4.75 mMd-1; Jalč et al., 2006c). We also need to mention here another structural carbohydrate, i.e. lignin. Lignin is not readily digestible in the process of ruminal fermentation. Limitation of digestion causes a reduced production of VFA, thus reducing methanogenesis (Van Soest, 1982). Moreover, the type of the used straw as well as refining processes of straw-containing feeds, such as ammonia treatment or leaching, result in a change in the molar proportions of acetic acid to propionic acid in ruminants (Hvelplund et al., 1978). Feeding of sheep using ammonia-treated wheat straw reduces the production of methane in comparison to wheat straw or barley straw, subjected to leaching or ammonia treatment (Moss et al., 1994).

\subsubsection{Nonstructural carbohydrates}

The limitation of the methanogenesis process may be caused by the transformation of readily digestible carbohydrates (starch) first of all to propionic acid, which may disturb horizontal hydrogen transfer and as a consequence limit the rate of the process. Moreover, a higher proportion of concentrate usually means a higher amount of starch in the feed ration, thus affecting a change towards fermentation. By lowering $\mathrm{pH}$ of the ruminal contents the capacity of methanogens to form methane is reduced (Lana et al., 1998; Russel, 1998). The level of $\mathrm{pH}$ in the rumen may also change depending on the frequency of feeding. If animals are fed the daily feed ration in two separate doses, $\mathrm{pH}$ in the rumen changes within the range from 5.85 to 6.65 , whereas in case of six doses fluctuations are lower, from 6.15 to 6.40 (Kaufmann et al., 1980). Less stable $\mathrm{pH}$ causes a reduction of methane emission by ruminants through an increased production of propionic acid (Jensen \& Wolstrup, 1977; Sutton et al., 1986), however, in modern feeding regimes such practices are used less frequently.

\subsection{Dietary fat}

Another method potentially influencing the process of methanogenesis consists in the addition of fatty acids, both saturated and unsaturated. Fat by affecting many metabolic processes may modify the amount of produced methane, and thus increase the energy value of the feed ration. In many countries nutrition standards for ruminants recommend an addition of fat at $2 \%$ to $8 \%$ in dry matter of the feed ration. The amount of added fat depends on its form and type (Cieślak et al., 2001; Szumacher-Strabel et al., 2009b; Martin et al., 2010). Palmquist \& Jenkins (1980) suggested feeding from 3 to $5 \%$ fat in diets for adult ruminants, thus increasing energy uptake at the simultaneous maintenance of the level of consumed fiber, in this way reducing the amount of fed starch. Substitution of starch with fat may result in the stabilization of ruminal processes (Palmquist, 1994; Szumacher-Strabel et al., $2001 \mathrm{a}, \mathrm{b}$ ). Grant \& Weidner (1992) were of an opinion that in the diets of adult cattle the amount of added fat should not exceed 700 - 900 gram per head, which constitutes from 6 to $8 \%$ in dry matter of the feed ration. Tackett et al. (1996) defined the maximum addition of rapeseed oil in the feed ration at $10 \%$. Enriching the feed ration with vegetable oils not only increases the amount of available energy, but also the amount of unsaturated fatty acids (UFA) in final products (Szumacher-Strabel et al., 2001c; Potkański et al., 2009; Cieślak et al., 2010). It needs to be stressed that UFA have a toxic effect on microbial cell walls by enhancing their permeability, as well as a gradual degradation, potentially reducing the numbers of microorganisms participating in changes, in which hydrogen is a by-product. For this reason the amount of available hydrogen will have a direct effect on the scale of 
methanogenesis. Moreover, methanogenesis may directly compete for hydrogen with the process of biohydrogenation occurring in the ruminal environment and deactivating UFA (unsaturated fatty acids). A common characteristic of both processes may be competition for the atom of hydrogen (Czerkawski et al., 1966). Plascencia et al. (1999) reported that the scale of ruminal biohydrogenation of fatty acids may be directly proportional to the estimated methane production. As a result of biohydrogenation UFA reduce the concentration of hydrogen ions in the environment, thus decreasing methanogenesis (Johnson \& Johnson, 1995; Cieślak et al., 2001). However, the total amount of hydrogen used in the saturation of UFA bonds is small (0.01) in comparison to the reduction of $\mathrm{CO}_{2}$ to methane (0.48), synthesis of volatile fatty acids $(0.33)$ or the utilization of hydrogen by bacterial cells $(0.12)$. For this reason in some studies no dependence was found between the process of biohydrogenation and methanogenesis (Czerkawski et al., 1966; Van Nevel \& Demeter, 1996).

On the basis of comparisons prepared to date, concerning the effect of the addition of fat to feed rations for ruminants, it was shown that every $1 \%$ added fat reduces methanogenesis by 2.2 to 5.6\% (Eugene et al., 2008; Beauchemin et al., 2008; Martin et al., 2010). According to the same data it may be stated that the influence of FA contained in fat depends on their nature. Other literature data point to the fact that the applied addition of fat in the nutrition of ruminants results in a modification of fermentation processes in the rumen; however, the amount of the addition depends on many factors and needs to be optimized continuously (Szumacher-Strabel et al., 2001c; Giger-Reverdin et al., 2003; Cieślak et al., 2004; Eugene et al., 2008). The European Union recommends the use of oils in feeding of ruminants, as a perfect alternative for other feed additives such as antibiotic growth stimulants, influencing microorganisms living in the rumen and participating e.g. in methanogenesis (Boadi et al., 2004; Monteny et al., 2006; Szumacher-Strabel et al., 2011b).

\subsubsection{Saturated fatty acids}

Studies concerning the effect of saturated fatty acids (SFA) on the process of methanogenesis in ruminants are typically based on oils containing considerable amounts of these acids. On the basis of conducted analyses it needs to be stressed that short chain fatty acids (SCFA) do not exhibit such properties in comparison to medium chain fatty acids (MCFA) C12:0, C14:0, which may significantly reduce methanogenesis (Dohme et al., 2004). Coconut oil is one of such SFA carriers constituting an important source of saturated medium chain fatty acids, i.e. lauric acid C12:0 and myristic acid C14:0 (Laureles et al., 2002). These acids were identified as substances strongly reducing microorganisms participating in methanogenesis (Dohme et al., 1999; Machmüller et al., 2003a). Thus, e.g. in studies conducted using a 7\% addition of coconut oil to the sheep feed ration a reduction of the protozoan count amounted to as much as $97 \%$ (Machmüller \& Kreuzer 1999). Results of previous experiments indicate that not all species of protozoans (e.g. Epidinium spp.) are eliminated from the rumen ecosystem after the application of the above mentioned experimental factor (Matsumoto et al., 1991). Moreover, Cieślak et al. (2006b) showed that a 5\% addition of coconut oil while reducing the population of protozoans increases the total count of bacteria in the RUSITEC system. In turn, Yabuuchi et al. (2006) recorded a considerable limitation of the ciliate population at the application of $2.0 \mathrm{~g}$ coconut oil per 11 ruminal fluid in comparison to the control as well as the experimental group with an addition of soybean oil. The reduction of the protozoan population in case of the application of coconut oil led to a 
reduction of methanogenesis. In studies conducted by Cieślak et al. (2006b) it was found that irrespective of the adopted proportion of concentrates in relation to forages the reduction of the protozoan count after the application of coconut oil at $5 \%$ was comparable. In turn, differences were recorded in the amount of formed methane at the application of the experimental factor in the feed rations with different proportions of structural carbohydrates. The authors were of an opinion that it suggests the potential effects of varying action of MCFA contained in coconut oil on the population of other microorganisms than protozoans, and participating in the formation of methane in the ruminal ecosystem. In earlier conducted investigations it was found that MCFA not only have a negative effect on the population of protozoans, but also methanogens. Another example presenting the effect of fat on the population of methanogens is provided by the experiment, in which coconut oil was added to the feed ration (Ipharraguerre \& Clark, 2003). Those researchers stated that the reduction of methanogenesis occurred through a direct action of acids contained in coconut oil on the population of methanogens in contrast to ionophore antibiotics, which reduced the production of $\mathrm{CH}_{4}$ inhibiting the activity of bacteria producing hydrogen (Ipharraguerre \& Clark, 2003). As it was shown in the other studies, conducted by Soliva et al. (2003a), lauric acid (C12:0) is more effective in the limitation of methanogenesis in comparison to myristic acid (C14:0). Additionally it was observed that the population of Archaea is reduced with the increase of content of lauric acid in the feed ration. For the first time in this study it was documented that the order-specific composition of the methanogenic population will be changed by MCFA, which directly indicated the effect of MCFA not only on the population of microorganisms (e.g. protozoa) producing a substrate for methanogenesis in the form of hydrogen. In other studies conducted by the same research team it was stated that a 24-h incubation of a mixture of C12:0 and C14:0, through a synergistic action, considerably reduces the production of methane in comparison to $\mathrm{C} 12: 0$ applied individually (Soliva et al., 2003b). A confirmation for this hypothesis is provided by further studies, in which it was shown that myristic acid may increase the negative effect of C12:0 on the emission of methane (Soliva et al., 2004a). In a review paper (Machmüller, 2006) a summary was presented concerning the results obtained to date on the effect of MSFA on methanogenesis occurring in ruminants both in vitro, and in vivo. It was shown in the analysis of the recorded results that the application of an amount even below 3\% MCFA of C12:0 and C14:0 in the feed ration results in the reduction of methanogenesis by $50 \%$. The author stressed that the limitation of methanogenesis in ruminants may be greater if: i) MCFA with higher proportions of C12:0 and C14:0 are applied, ii) animals are fed with feed rations containing higher proportions of concentrates, iii) feed rations are supplemented with soap-forming minerals and if the daily amount of MCFA is divided into smaller portions, thus providing a cyclical supply of MCFA to the rumen environment. It results from the above mentioned information that the application of MCFA is more effective in relation to methanogenesis at intensive feeding than in case of extensive feeding.

\subsubsection{Unsaturated fatty acids}

Feeds of plant origin contain varied amounts of ether extract, while unsaturated fatty acids (UFA) are the dominant acids in the fatty acid profile. The greatest amounts of ether extract are found in seeds of oil crops (approx. 45\%) as well as their oils (even up to $99 \%$ ). The primary source of oleic acid is e.g. rapeseed oil (approx. 62\%), for linoleic acid it is sunflower oil (approx. 64\%), while for linolenic acid it is linseed oil (approx. 53\%). UFA may 
have a multifaceted effect on the production of methane in the ruminal ecosystem through a direct action on the population of bacteria, protozoa or methanogens, as well as - to a limited degree - by a reduction of the amount of available hydrogen (biohydrogenation). Machmüller (2006) stated that the range of action of fatty acids on microorganisms living in the rumen depends on the following factors: the type of used acid source, amount and frequency of its application as well as the share of concentrates in the feed ration. This confirms earlier observations reported by Henderson (1973), who stated that the count of microorganisms in the rumen is influenced not only by the composition, but also by the fatty acid profile of the feed ration as well as the amount of applied fatty acids. According to Dong et al. (1997), it also depends on the type of applied fatty acids. Most frequently FA have a negative effect on the population of cellulolytic bacteria, hindering the access of these microorganisms to feed particles, or directly through their toxic effect on bacterial cells (Dong et al., 1997; Hristov et al., 2004). In other experiments it was shown that the negative effect of the addition of long chain fatty acids (LCFA) is probably caused through an action on the cell membrane, particularly of gram-positive bacteria. It has been shown in vitro that linolenic acid is particularly toxic for the 3 cellulolytic bacterial species (Fibrobacter succinogenes, Ruminococcus albus, and Ruminococcus flavefaciens), because it disrupts cell integrity (Maia et al., 2007). Here it needs to be stressed that the previously conducted studies showed a dependence between cellulolytic bacteria and methanogens (Morvan et al., 1996). In other studies it was found that the $F$. succinogenes population was reduced markedly by an increasing degree of unsaturation and inclusion level of unsaturated C18fatty acids, while $R$. flavefaciens was inhibited only by linoleic and linolenic acids at a high level (Zhang et al., 2008). Those authors indicated an ambiguity in the response of microorganisms on the applied acids. The observed reduction of the bacterial population may be explained by chemical properties of fatty acids. Due to the long non-polar carbon chain, as well as the polar hydroxyl group, FA behave similarly to detergents. These substances as a result of interaction with the cell membrane of microorganisms cause a reduced surface tension in the lipid bilayer and the generation of "holes", through which ions escape to the medium, thus leading the cell to destruction. Moreover, in the presence of long chain fatty acids (LCFA) in the medium genes engaged in LCFA transport through the cell membrane. Membrane proteins FadL and FACS are responsible for the transfer of FA through the lipid bilayer (Black \& DiRusso, 2003). In certain bacteria, e.g. Escherichia coli, excessive accumulation of fatty acids in the cell leads to the activation of genes engaged in $\beta$ oxidation, which facilitates FA utilization and their use as a source of energy and carbon (Hearn et al., 2009). At the time when excess LCFA are found in the medium, this mechanism is disturbed, which as a consequence leads to cell death (Black \& DiRusso, 2003). The action of long chain fatty acids on selected species of bacteria that take part e.g. in ammonia formation was also confirmed by Maczulak et al. (1981). In studies conducted by those authors it was shown that palmitic as well as stearic acids reduce the growth and development of Bacteroides ruminicola and Butyrivibrio fibrisolvens, while oleic acid stimulates the development of Selenomonas ruminantium, Bacteroides ruminicola and Butyrivibrio fibrisolvens. Moreover, we may find in literature other examples than only negative for the influence of vegetable oils on the bacterial population. Dohme et al. (2001) observed that an addition of stearic acid as well as linoleic acid at $50 \mathrm{~g} \mathrm{kg-1}$ DM does not have a negative effect on the total count of discussed microorganisms. In turn, other studies showed a positive 
effect of oils on the synthesis of microbial proteins reflected in the activity of microorganisms, including bacteria (Broudiscou et al., 1994, Szumacher-Strabel et al., 2001a; Jalč et al., 2006d). A lack of definite results concerning the effect of an addition of vegetable oils on the population of bacteria may be e.g. related with the type of applied carbohydrates in the feed ration. A smaller negative effect of the addition of used oils was observed in feed rations with the predominance of structural carbohydrates in comparison to non-structural carbohydrates (Cieślak et al., 2006 b; Jalč et al., 2006a; Machmüller et al. 2006). It needs to be remembered that it is possible to provide such supplementation with fat that it does not have a negative effect on the processes occurring in the rumen as well as the composition of fat in animal products (Cieślak et al., 2010; Cieślak et al., 2009b; Szumacher-Strabel et al., 2011b). According to other data, only the addition of fat at an amount greater than $5.0 \%$ dry matter has a toxic effect on ruminal microorganisms, including bacteria (Woolcock, 1991). In case of the influence of the addition of oil on the population of protozoans the dependence between the population size of these microorganisms and the extent of methanogenesis seems closer due to the fact that protozoans are the greatest producers of hydrogen in the rumen ecosystem. It was found that there is also a physical link between protozoans and methanogenesis, thus protozoans are responsible in 9 to $37 \%$ for methanogenesis in the rumen (Finlay et al., 1994; Newbold et al., 1995). For this reason the reduction of the population of protozoans, accounting for up to $35 \%$ of the rumen microbial mass (Williams \& Coleman, 1992) may cause a direct reduction of the population of methanogens, and in this way also the extent of methanogenesis. Similarly as in case of the unclear effect of fatty acids contained in oils on bacterial counts, and similarly as it is the case with the population of protozoans data are also ambiguous.

Most frequently to date a negative effect of both SFA and UFA has been reported, in the pure form and in mixtures, in the liquid and solid form, in vitro and in vivo on the total population of protozoans or individual dominant species (Ivan et al., 2001; Hristov et al., 2004; Soliva et al., 2004b, Zhang et al., 2008; Beauchemin et al., 2009). In studies conducted by Szumacher-Strabel et al. (2004) it was shown that a 5\% addition of rapeseed oil (a source of C18:1), sunflower oil (source of C18:2) or linseed oil (source of C18:3) caused a limitation of total protozoan counts in the rumen by $19 \%, 31 \%$ and $35 \%$, respectively, which was connected with a reduction of methanogenesis by 27,35 and $50 \%$, respectively. The authors pointed to the fact that with an increase in the number of unsaturated bonds in analyzed oils, the degree of the effect on the process of methane formation increased in the rumen ecosystem. These results were confirmed by studies conducted by Varadyova et al., (2007). A significant effect was observed of $5 \%$ linseed oil added to the diet with a meadow hay:barley grain ratio $(80: 20 \%)$ on the rumen ciliate population; the total protozoan concentration and the number of Entodinium spp. were reduced as well as Dasytricha ruminantium, Isotricha spp., Polyplastron multivesciculatum, Ophryoscolex tricoronatus and Eremoplastron dilobum. Similarly as in case of a study by Ivan et al. (2001), in which it was found that the use of $6 \%$ sunflower oil caused a considerable reduction of the population of protozoans Entodiniomorpha as well as the total defaunation of ciliates Holotricha. In both above mentioned cases, the limitation of the counts of protozoans could have been connected with a reduction of methanogenesis. However, both in studies conducted by a team of Varadyova et al., (2007) and Ivan et al., (2001) unfortunately methane production was not determined. In other studies a $6 \%$ addition of soybean lipids caused a $37 \%$ 
reduction of methane emission (Jordan et al., 2006a), while a 5.8\% addition of linseed oil reduced it by as much as 52\% (Martin et al., 2008). Due to above, the authors (Martin et al., 2008) stated that the application of linseed oil as an FA carrier seems a highly promising addition to feed rations for ruminants in terms of ruminal methanogenesis. Beauchemin et al. (2009) reported that the emission of methane by dairy cows to a higher degree was limited in case of the application of linseed or rapeseed in comparison to sunflower seeds, by 17 and $10 \%$, respectively. On the basis of studies conducted by other research teams, in which pure linoleic acid was added to the feed ration, only a statistically significant reduction was found of both total protozoan count and the production of methane (Dohme et al., 2001), and such conclusions need to be drawn with caution. According to Cieślak et al. (2011, unpublished data) the effect of FA on protozoan counts depends not only on the type, but also the concentration of the discussed experimental factor, as well as particular species of protozoa. This study showed a varying effect of pure forms of fatty acids applied at different concentrations on populations of Entodinium caudatum (EC), Eudiplodinium maggii (EM) and Epidinium ecaudatum (EE) in long-term (28 days) monocultures. The most toxic effect was exerted by the following FA: stearic acid, linolenic acid, oleic acid and linoleic acid for the EC population, and linolenic, oleic and stearic for EE. The linoleic acid was not toxic to the EE population. The EM population was the most resistant to the investigated FA and only stearic and linolenic fatty acids reduced protozoan numbers. In those investigations it was also stated that individual analyzed monocultures differ in the amounts of produced methane. The EE and EM control monocultures produced on the average higher amounts of methane $(0.77$ and $0.74 \mathrm{mmol}$, respectively) when compared to the EC control $(0.54 \mathrm{mmol})$. The above hypotheses may be partly explained by a lack of a negative effect of the addition of oils on the population of the analyzed rumen ciliates in case of some studies (Matsumoto et al., 1991; Cieślak et al., 2006a; Kisidayova et al., 2006; Cieślak et al., 2009a). A 5\% addition of evening primrose oil containing considerable amounts of C18:2 and C18:3 caused a reduction of the counts of Dasytricha ruminantium, Isotricha spp. as well as Polyplastron multivesciculatum, while on the other hand increasing the population of Entodinium spp. by $32 \%$ and Diploplastron affine by $21 \%$ (Kisidayova et al., 2006). In other studies, in which a carrier of the C18:2 acid was used, it was shown that Isotricha spp. and Dasytricha spp. as well as cellulolytic protozoans (Polyplastron spp., Diplodinium spp., Enoploplastron spp.) are more sensitive to the action of the discussed acid than protozoans Entodinium spp (Ivan et al., 2001). In case of oleic acid a 5\% addition of rapeseed oil (the primary carrier of this acid) in dry matter of the substrate to the culture medium of Eremoplastron dilobum in short-term $(24 \mathrm{~h})$ incubation, limiting the production of methane by $14 \%$ did not have a negative effect on the population of analyzed protozoans (Cieślak et al., 2006a). In the opinion of those authors it suggests that other microorganisms participating in methanogenesis or their metabolic activity were in a certain way reduced, thus influencing the reduction of the amount of methane formed in the rumen. Similar results were previously recorded by Wettstein et al. (2000), who as a result of a $7.7 \%$ addition of canola seeds and a 3.1\% addition of canola oil caused a reduction of methanogenesis by approx. $26 \%$ without the reduction of protozoan counts in the rumen. In other studies it was found that rumen ciliates Entodinium caudatum and Diploplastron affine and their associated bacterial populations exhibited different metabolic responses to the form and concentration of linoleic acid (Cieślak et al., 2009a). Differences in the observations may additionally result e.g. from different rumen fluids used in analyses (species and 
individual differences). Moreover, some authors suggest that the discussed microorganisms have a limited ability to assimilate, transform and utilize fat in the feed ration (Ivan et al., 2001). However, to date the level of FA addition has not been determined, which would influence the above mentioned factors. According to Ivan et al. (2001), this level is $10 \mathrm{mg} / \mathrm{L}$ in case of linoleic acid, while Kisidayova et al. (2005) suggested that an inhibition of growth and development of Diplodinium spp. and Entodinium spp. is caused already by $3 \mu \mathrm{g} / \mathrm{L}$ of this acid. Such differences may have been caused by conditions (in vitro vs. in vivo), under which the experimental factor, i.e. the fat addition, was applied. Martin et al. (2010) reported that in case of experiments conducted in vitro, it may be definitely stated that the emission of methane is reduced with an increase in the level of fat addition. Differences in recorded results depending on the experimental conditions were also shown in case of the application of other long chain fatty acids. In in vivo experiments, in which an addition of fish oil (a carrier of eicosapentaenoic acid - C20:5; docosahexaenoic acid - C22:6) was used in the mixture with other oils, a slight effect was found on the production of methane (Woodward et al., 2006). In turn, in studies conducted in vitro a considerable reduction of $\mathrm{CH}_{4}$ level was observed under the influence of the applied experimental factor in the form of fish oil (Dong et al., 1997; Fievez et al., 2003). Similar results were shown in investigations conducted by Jalč et al. (2006c), in which the reduction of ruminal methanogenesis through an addition of fish oil was $23 \%$. However, the authors showed that this limitation was comparable in its extent as in case of the application of linseed oil. It is suggested that there are still many ambiguities in the influence of FA on the populations of individual protozoan species and thus the process of methanogenesis.

Development of modern molecular techniques extended the range of identifiable microorganisms in different media, e.g. in the rumen ecosystem. State-of-the-art methods of molecular biology, based on rRNA analysis and independent of in vitro cultures, facilitate a better characteristic of the quantitative and qualitative composition of the ruminal methanogen population (Pers-Kamczyc et al., 2011).

Thus, the possibility to determine the effect of LCFA was extended to other microorganisms participating in methanogenesis, such as methanogens. Similarly as bacteria, methanogens are one of the earliest organisms colonizing the rumen. Archaea are found in the forestomach of lambs already $30 \mathrm{~h}$ after birth (Morvan et al., 1994). The population of these microorganisms in lambs in the first week of life is $10^{4}$ cells/g contents, while in the third week of life it is already $10^{8}-10^{9}$ cells/g (Skillman et al., 2006). Methanogens appearing the earliest in the rumen belong to the genus Methanobrevibacter (Skillman et al., 2006). In case of Methanobacterium, representatives of this family rapidly colonize the rumen environment; however, in contrast to Methanobrevibacter they rapidly disappear, i.e. at day 12 - 19 after birth (Zhu et al., 2007). Similarly as bacteria, Archaea living on solid particles may represent a considerable portion of the total population of methanogens in the rumen (Tajima et al., 2001). Zhu et al. (2007) mentioned Methanobrevibacter spp., Methanosphaera spp. as well as unidentified methanogens as species characteristic of that fraction. In turn, Shin et al. (2004) indicated that the most numerous group of Archaea living on solid particles comprises the families of Methanomicrobiaceae and Methanobacteriaceae. Methanomicrobium mobile, Methanobacterium aarhusense as well as Methanosphaera stadtmanii are species found only as forms floating in the rumen fluid, which constitute a slight percent of the total population of Archaea (Zhu et al., 2007). 
A $10 \%$ addition of rapeseed oil as an LCFA carrier in feed rations composed mainly of concentrate under in vitro conditions caused a statistically highly significant decrease in the production of methane, amounting to $44 \%$ (Dong et al., 1997). The authors in their investigations showed that the main cause of such a high reduction of methanogenesis was connected with the negative influence of fat on the population of methanogens. This is confirmed by the experiences of other researchers, in which using pure forms of fatty acids from the C18 group a reduction in the population of methanogens was recorded (Zhang et al., 2008). However, the authors of those studies stressed that the degree of the effect of applied fatty acids depends on their type as well as concentrations. Among the used acids linolenic acid turned out to be the most toxic acid. In turn, stearic acid irrespective of the applied concentration ( 35 or $70 \mathrm{~g} / \mathrm{kg}$ dry matter) caused an increase in the population size of methanogens without a limitation of the amount of produced methane. Moreover, it was found that protozoans in case of the application of C18 fatty acids are more sensitive than methanogens. In other experiments using wild dog rose seed oil an $8 \%$ decrease in methane production was recorded after $48 \mathrm{~h}$ of fermentation, whereas the methanogen concentration tended to increase by 14.5\% (Szumacher-Strabel et al., 2011b). These studies may indicate the fact that other factors, such as the activity of individual species of methanogens should be taken into consideration. It was previously confirmed in studies on the activity of bacteria after the application of feed rations containing both saturated and unsaturated acids (Kowalczyk et al., 1977, Ivan et al., 2001).

\subsection{Phytogenic dietary additives as a source of secondary plant metabolites}

Since 1 January 2006 legal regulations concerning animal feeds issued by the European Union prohibited the application in animal nutrition of feed additive antibiotics, frequently called antibiotic growth promotors (Directive EU 1831/2003). The main reason for the introduction of this regulation was connected with the increasingly negative attitude of the public to the feed additives used so far. Reports appeared on a dependence between antibiotics used in animal nutrition and growth of antibiotic-resistant bacterial strains, including also those pathogenic to humans (Barton, 2000; Hurd, 2005). Increasing problems resulting from the implementation of the EU directive 1831/2003 forced dairy cattle breeders and producers to search for new alternative solutions, which application would improve production performance, contribute to higher feed conversion ratios, greater body weight gains, appropriate regulation of gastrointestinal microflora, as well as reduce emissions of ammonia and methane.

An alternative which could ensure the development of new, non-antibiotic growth stimulants, mainly of plant origin, comprises e.g. herbs and plant extracts together with the contained bioactive compounds.

The field of science investigating biologically active substances in herbs, that means secondary metabolites of plants is called pharmacognosis. To date we have discovered approx. 35000 secondary metabolites and $50 \%$ production of the pharmaceutical industry is based on the utilization of bioactive substances.

Secondary metabolites serve an important ecological function acting as chemical communicators between plants and the environment (Calsamiglia et al., 2007). Gershenzon \& Croteau (1991) discovered and published the antimicrobial and antiseptic effect of biologically active substances. 
Secondary metabolites are difficult to classify and it is connected with the problems in the determination of the proper and complete mechanism of their action and pathways of their synthesis. In the recent period 3 groups of compounds were identified, to which on the basis of conducted studies different types of secondary metabolites are classified.

The following groups were identified:

- $\quad$ essential oils

- saponins

- tannins.

All the above classes of defined compounds are characterized by a specific biological activity. In case of these compounds the accumulated knowledge, the effects and manner of action on microbial fermentation in the rumen have become relatively well-known but still series of studies are required together with a confirmation, not only in vitro, but first of all in vivo.

Effects of phytogenic additives, rich in secondary plant metabolites on methane and ammonia production are not yet clear (Benchaar et al., 2008). Some data proved potentially antimicrobial properties of secondary plant metabolites against a wide range of rumen microorganisms and hence rumen microbial fermentation e.g. decreased ammonia production (Busquet et al., 2006), some indicated no effect on the ammonia concentration (Busquet et al., 2005). Effect of active components depends on their chemical structure, constituents and concentration (Śliwinski et al., 2002, Castillejos et al. (2006). Calsamigila et al., (2007) concluded that essential oils being the source of secondary plant metabolites may inhibit the deamination and methanogenesis that results in lower ammonia and methane concentration.

\subsubsection{Essential oils}

Essential oils are a mixture of secondary metabolites. They are connected with plants described as 'herbal', 'spice' or 'aroma' (Greathead, 2003). They are responsible for the characteristic aroma ('quinate essentia') of these plants and may be obtained using steam distillation or extraction with the application of solvents. Many of them seem to have bactericidal and bacteriostatic effects. They act against bacteria, as well as fungi, viruses and protozoans (Greathead, 2003). Studies by Covan (1999) indicate that $60 \%$ preliminarily tested essential oils indicate an inhibitory action in relation to the development of fungi and $30 \%$ in relation to bacteria. Studies on the antibacterial action were also conducted by Chao \& Young (2000), Smith-Palmer et al. (1998), Dorman \& Deans (2000), Wallace et al. (1994), Wang et al. (2000) and Goel et al. (2008). One of the potential mechanisms of action in these compounds is related with the inactivation of extracellular enzymes (Bruel \& Coote, 1999) and damage of cell walls (Greathead, 2003). Essential oils also influence electron transport, ion gradients, protein translocation and other enzyme-dependent reactions (Greathead, 2003).

Studies published in 2006 by Casteillejos et al. and Busquet et al. indicate a highly advantageous effect of biologically active components on ruminal fermentation. However, they also showed the adaptability of certain groups of microorganisms to applied factors in case of their long-term action. The best effects were observed in investigations conducted in 
the closed management system, which is characterized by a limited duration of the experiment. Previously conducted studies suggested the influence of essential oils on ruminal fermentation processes maintained to the advantage of propionic fermentation. By influencing the modification of the fermentation process they contribute to changes in the composition of animal origin products, providing them with health-promoting properties.

Results of investigations conducted to date do not yield definite answers taking into consideration the type and concentration of the applied oil, or the secondary metabolite itself, which could effectively replace feed antibiotics. Appearing discrepancies as well as literature data suggest the advisability of further studies in order to gain insight into the problem and broaden our knowledge on the application of additions of appropriate essential oils in feed rations for ruminants.

Essential oils in terms of their chemical structure comprise multi-component mixtures of compounds. All these compounds are hydrocarbons, alcohols, aldehydes, ketones, esters or ethers (Hristov et al., 2007). Essential oils may contain derivatives of acetylene, phenylpropan, as well as sulfur and nitrogen compounds, coumarins and other rarely found compounds with a non-terpene structure. The most active components contained in these mixtures belong to two most important chemical groups (Casteillejos et al., 2007):

- $\quad$ terpenoids (terpenes)

- phenylpropanoids.

Essential oils are a group of compounds among secondary metabolites of plant origin (tannins and saponins), which selected properties are still to be discovered and identified. However, knowledge gained in recent years makes it possible to state that essential oils are a highly varied pool of compounds exhibiting high chemical reactivity and biological activity. We define them as compounds which:

- $\quad$ are soluble in ethanol, fats and solvents of fatty acids

- have a polar structure and are composed of lipophilic and hydrophilic ionic groups

- density is usually lower than that of water

- $\quad$ are practically insoluble in water

- at room temperature are liquids, most frequently oily

- boiling point ranges from 50 to $320^{\circ} \mathrm{C}$

- $\quad$ are optically active substances, which means that they are found in the D and L forms

- most frequently are colorless substances, but they are also brown, bluish and greenish

- in the plant world are used to attract insects, serve a defense function, facilitate wound closure and hinder evaporation from leaf surface

- $\quad$ within the entire family of essential oils there are also oils, which products are used in aromatherapy and pharmacological industry

- constitute substrates for the production of pigments and vitamin A

- exhibit extensive applications in medicine:

- $\quad$ are used in the control of cardiovascular diseases

- exhibit carcinogenic action, neutralizing the negative, rapid and uncontrolled increase in the numbers of free radicals

- improve taste, have an advantageous effect on digestion processes and thus contribute to the inhibition of excessive intestinal fermentation in the organisms of ruminants 
- $\quad$ essential oils, similarly as the other group of secondary metabolites (saponins, tannins) have been proven to exhibit major antimicrobial and antiseptic properties. These specific properties are directed against a wide range of microorganisms, including bacteria, protozoans and fungi (Benchaar et al., 2007) and hence may have antimethanogenic and antiammonia formation properties.

Certain plant extracts, including essential oils, similarly as most antibiotics exhibit bacteriostatic and bactericidal properties. The broad range of their antibacterial action is connected with their chemical structure. Essential oils are derivatives of phenols (aromatic hydrocarbons), thus to a considerable degree they have comparable chemical and biological properties. Phenols and other surfactants have the ability to inhibit bacterial development and growth and to kill bacterial cells. These compounds, as well as the identified essential oils at an adequate concentration act as bactericidal agents. This antibacterial activity is a consequence of their ability to contact with the membrane of bacterial cells. Essential oils as lipophilic compounds change the structure of the cell membrane, which also has a similar polar structure (membranes are composed mainly of lipids and proteins), disturbing their functions by leading to a drop in ion gradient and loss of its stability (Griffin et al., 1999; Calsamiglia et al., 2007). In most cases bacteria may prevent such a phenomenon by using appropriate ionic pumps, equalizing occurring changes in the gradient of concentrations. Such a response on the part of bacteria would protect cells from death (Griffin et al., 2001; Cox et al., 2001). Unfortunately, such an action in which a cell loses large amounts of energy contributes to a reduction of growth and development, which as a consequence leads to more serious changes in the fermentation profile of the rumen.

When analyzing the mechanism of action of essential oils it may be stated that they should be more effective in their antibacterial action against strains of gram-positive bacteria, which cell membranes interact directly with the hydrophobic compounds of essential oils (Smith-Palmer et al., 1998). Similarly, Burt in 2004 suggested that gram-positive bacteria seem to be more sensitive to the antimicrobial action of essential oils than gram-negative bacteria. Gramnegative bacteria have an additional, bilayer inner membrane, lining the cell wall from the inside. This membrane is characterized by a complex structure (proteins, phospholipids, liposaccharides), and apart from the mechanical function, which it serves in the cell, it also plays the role of a certain permeability barrier limiting access of hydrophobic compounds. However, some biological agents contained in essential oils, such as e.g. thymol and carvacrol, caused growth inhibition also in gram-negative bacteria by disturbing the proper function of the inner membrane. Conclusions stemming from the above observations show that in case of selected essential oils and specific contained biologically active compounds (e.g. thymol and carvacrol) an effective action against both gram-positive and gram-negative bacteria is possible (Calsamiglia et al., 2007). However, effects of secondary plant metabolites on methane and ammonia emission are still unexplored areas. For example our findings on the effect of essential oils and particular secondary plant metabolites did not confirm the direct antimethanogenic effect when eugenol and vanillin were supplemented to dairy cow ratio analyzed in Rusitec system (Szumacher-Strabel et al., 2009), whereas limonene affected rumen methanogenesis inhibiting the methanogens populations (Cieślak et al., 2009c).

\subsubsection{Saponins}

Saponins comprise a numerous group of glycosides, found in angiospermous plants. The property distinguishing them from the other glycosides is the reduction of surface tension 
(Sparg et al., 2004). The name "saponin" originates from the Latin word sapo [soap], since saponins are water-soluble substances, capable of forming foam and saponification (Oleszek, 2002; Vincken et al., 2007). These properties result from their structure. Saponins are composed of hydrophobic sapogenin, i.e. aglycone and the hydrophilic part of the saccharide, i.e. glycone, most frequently comprised by glucose, arabinose, xylose and galactose. Ages ago plants containing saponins were considered valuable and used in medicine, herbology, pharmacology as well as cosmetology. They were used e.g. as detergents, for example root of soapwort Saponaria officinalis L., and thanks to traditional Chinese medicine worldwide acclaim was given to properties of saponins contained in roots of ginseng Panax ginseng C. A. Mey. (Sparg et al., 2004). Saponins are substances which protect plants against bacterial and fungal infections. Saponins by changing the structure of cell membranes (and thus also that of epithelia) make them more readily permeable for organic components. They trigger the secretion of gastric fluid, bile and intestinal fluid. Saponins exhibit antibacterial, antiprotozoal and antiviral properties. Some of them are capable of binding toxins and metabolites. Properties of saponins are to a considerable degree influenced by the volume of the applied feed ration. In case of saponin overdose they exhibit a disadvantageous effect on the organism. This type of action comprises the following effects: hemolytic, nephrotoxic, hepatotoxic, as well as antinutritional, consisting in the inhibition of active nutrient transport.

The potentially advantageous action of saponins in the rumen, including the antibacterial, antiprotozoal, antifungal as well as antimethanogenic effect, is indicated by the results of studies conducted in recent years by many authors (Agarwal et al., 2006; Goel et al., 2008; Patra and Saxena, 2009). However, those researchers pointed to the fact that the effects of saponin administration depend on many factors, including the time of application (Wina et al., 2006).

Many studies conducted to date showed that the addition of saponins to feed rations for ruminants, irrespective of their source (Yucca schidigera, Sapindus saponaria, Sapindus rarak) reduces methanogenesis (Śliwiński et al., 2002; Ningrat et al., 2002; Hess et al., 2003a, 2004; Wang et al., 2009). Similarly as in case of fat supplementation, saponins added directly to feed rations may influence microorganisms participating in the process of methane formation in the rumen. This effect is multifaceted, affecting both microorganisms participating in the production of hydrogen, e.g. protozoans, and microorganisms utilizing this hydrogen to produce methane (Szumacher-Strabel \& Cieślak, 2010). This hypothesis is confirmed by earlier studies, in which antimicrobial action of saponins was shown in case of organisms colonizing the rumen (Benchaar et al., 2007a). The population of protozoans, ruminal microorganisms indirectly connected with methanogenesis, was completely reduced thanks to the addition of saponins coming from Yucca schidigera (Wallace et al., 1994). The probable cause of the destruction of protozoan cells was the chemical structure of saponins. Saponins are composed of hydrophobic sapogenin, i.e. an aglycone, and a hydrophilic saccharide part, i.e. a glycone, which may comprise glucose, arabinose, xylose and galactose. Saponins are classified on the basis of their aglycone structure into two groups: steroid (C27), derivative of spirostane or furostane, and triterpene (C30), having triterpene aglycone (Sparg et al., 2004). These compounds may interact with cholesterol found in membranes of eukaryotic cells, causing cell destruction (Cheeke, 1999; Wina et al., 2005). In studies on the effect of saponins coming from tea on pure cultures of methanogens predominating in the ruminal fluid (Methanobrevibacter ruminantium) no negative influence 
was observed on the counts of these microorganisms (Guo et al., 2008). Similarly, in a study conducted by a team of Mao et al. (2010) it was shown that the reduction of methane emission from growing lambs was not caused by a direct action of tea saponins on methanogens, but rather on the population of protozoans, in this way limiting the amount of available hydrogen for the process of methanogenesis. The authors indicated that those observations were consistent with the previously reported results of in vitro experiments, in which methanogenesis was reduced with no decrease in the population of methanogens under the influence of the same saponin carrier (Hu et al., 2005). The lack of a negative action of saponins on the population of methanogens was also recorded in other studies, where Sapindus saponaria was applied at $100 \mathrm{mg} / \mathrm{g}$ dry matter (Hessa et al., 2003b). Similarly as in case of the earlier reports a $20 \%$ reduction of methanogenesis was directly connected with a $54 \%$ reduction of the protozoan population. However, not all literature data confirm a lack of a negative influence of saponins on populations of methanogens. An experiment conducted using saponins from fruits of Sapindus rarak showed that a reduction of methanogen RNA concentration was obtained at the application of the highest concentration of the tested experimental factor in the feed ration $(4 \mathrm{mg} / \mathrm{ml})$, while lower concentrations did not have an effect on the populations of these microorganisms (Wina et al., 2005). A reduction of protozoan populations, both in vitro and in vivo, was also recorded after the application of an extract from Yucca schidigera (YSE; Hristov et al., 1999; Pen et al., 2006). However, it needs to be remembered that the use of YSE did not always reduce the populations of protozoans. In investigations conducted by Benchaar et al. (2008) no negative effect was found of $60 \mathrm{~g}$ YSE (containing 10\% saponin) per cow a day on the total numbers and the distribution by genera of ruminal ciliate protozoa. Similarly, other authors did not show any such effect (Hristov et al., 2003; Bahh et al., 2007). The observed differences may have been caused by the amount of applied saponins (Hristov et al., 2004). This hypothesis may be confirmed by the investigations conducted by our research team. The use of an extract from Knautia arvensis only at higher doses (50.0 and $100.0 \mathrm{mg} / 40 \mathrm{~mL}$ of culture) caused a reduction of methanogenesis. In contrast, lower concentrations $(0.5,2.5,5.0,12.5$ and $25.0 \mathrm{mg} / 40 \mathrm{~mL}$ of culture) did not reduce the amount of produced methane (Szumacher-Strabel et al., unpublished data). In other studies conducted by our team using roots of Saponaria officinalis as a saponin carrier at 0,4,10,20, 40, 100 and $200 \mathrm{mg}$ per $40 \mathrm{ml}$ of culture the reduction of methanogenesis was as low as 12 to $26 \%$ at higher concentrations (from 40 to $200 \mathrm{mg}$; Zmora et al., unpublished data). Moreover, it was shown that the limitation of methane production was caused by the reduction of the population of protozoans, both Entodiniomorhpa and Holotricha. These studies also showed that lower concentrations of saponins coming from roots of Saponaria officinalis may have a stimulating effect on the population of protozoans, increasing slightly the amount of formed methane. Other causes of a lack of the effect of saponins on processes occurring in the rumen as well as counts of protozoans may be related with the total degradation of saponins (Makkar \& Becker 1997), hydrolysis (Miles et al., 1992; Teferedegne et al., 1999) or deglycosylation (deglycosylate) (Wang et al., 1998). Odenyo et al. (1997) stated that the manner of saponin administration influenced the population of microorganisms in the rumen. In the conducted experiment $300 \mathrm{~g}$ Sesbania sesban introduced directly to the rumen had a toxic action on the population of protozoans, while saponins administered to animals together with feed did not show such properties. According to the researchers, the result may be explained by 
rumination of feed by animals, since in this way amylase contained in saliva causes detoxication of saponins.

Goel et al. (2008) additionally pointed to differences in the composition of feed rations as a factor potentially differentiating the effect of saponins on methanogenesis. When feeding a feed ration with a predominance of concentrates rich in starch we may more effectively inhibit methanogenesis in comparison to the effect of a feed ration, in which forages predominated. When using saponins as the agent limiting the production of methane by the reduction of protozoan counts we also need to consider the passing antiprotozoal action, directly dependent on the time of action (Newbold et al., 1997, Teferedegne et al., 1999). As it was already mentioned, protozoans are not resistant to saponins; however, theses substances through the action of bacteria in the rumen environment may be subjected to the process of detoxication, and the time during which it takes place is a significant element of this process (Teferedegne et al., 1999; Teferedegne, 2000).

Many studies also indicated the action of saponin on populations of anaerobic fungi in the rumen ecosystem (Mao et al., 2010; Wang et al., 2011). In vitro experiments showed that the counts of fungi were reduced under the influence of saponins coming from Yucca schidigera or Sesbania pachycarpa (Wang et al., 2000; Muetzel et al., 2003). Saponins from fruits of Sapindus rarak completely eliminated fungal RNA already at the lowest concentration (1 $\mathrm{mg} / \mathrm{ml}$ ) of the experimental factor in the feed ration, while the highest concentration (4 $\mathrm{mg} / \mathrm{ml}$ ) caused a reduction of the methanogen RNA concentration (Wina et al., 2005). This suggests, similarly as in case of protozoans, that fungi are more sensitive to the action of saponins than methanogens. Thus saponins reducing the populations of fungi cause a reduction of available hydrogen in the rumen environment. In another experiment, in which gynosaponins extracted from Gynostemma pentaphyllum were applied at 50, 100 as well as $200 \mathrm{mg} / 1$ in the co-culture of a fungus Piromyces sp. F1 and a methanogen Methanobrevibacter sp., a reduction was stated both for the counts of methanogens and the production of methane at all the applied doses (Wang et al., 2011). In contrast, lower concentrations (50 $\mathrm{mg} / \mathrm{l}$ ) did not reduce the population of fungi. The increased fungi numbers in case of low doses of gynosaponins are probably due to the sugar moiety of saponin as a nutrient for microorganisms (Wang et al., 2011). This suggests that researchers when interpreting recorded results have to take into consideration the potential occurrence of an interaction between substances or compounds contained in extracts and a biologically active agent. An example of these interactions was presented in a study conducted using garlic (Kamel et al., 2008). An addition of garlic to the rumen fluid caused a reduction of methanogenesis by $19.5 \%$, whereas an addition of allicin, one of the compounds of garlic oil, did not change $\mathrm{CH}_{4}$ production. On the basis of that experiment it may be concluded that allicin alone does not exert an inhibitory effect; however, its interaction with some unidentified garlic components cannot be ruled out. In turn, in other studies after the application of $0.1,0.2$ or $1.0 \mathrm{mg}$ of xanthohumol (an isolated biologically active agent from hops) it was found that all concentrations of the applied experimental agent caused a reduction of methanogenesis in the rumen environment (Zmora et al., 2012). Presented examples suggest that in the analysis of the effect of individual biologically active substances on processes occurring in the rumen environment, in the pure form or e.g. in extracts, we need to consider the possibility of such interactions as those mentioned above. In view of the above, an interpretation of recorded results is sometimes very difficult. 


\subsubsection{Tannins}

Tannins are polyphenolic compounds, with a high molecular weight and capacity to form complexes with other compounds, especially proteins (Barszcz \& Skomial, 2011). Tannins are formed via shikimic pathway and are divided into hydrolyzable and condensed (nonhydrolysable; proanthocyanidins). The basic unit for hydrolyzable tannins is gallic acid $(3,4$, 5-trihydroxyl benzoic acid), and flavone (oligomers or polymers of flavonoid units) for condensed one. Hydrolyzable tannins comprise two classes: gallotannins and ellagitannins (Figure 1). Gallotannins are formed of units of gallic acid surrounding a polyolic core. The most common source of gallotannins is tannic acid, whereas ellagitannins may exist in the form of ellagic acid units surrounding a polyolic core but at least 2 of them are linked through carbon-carbon bonds. Proanthocyanidins are polymers of flavon-3-ol (catechin) units (Figure 2) and exist most often as cyaniding and delphinidin. According to Kowalik et al. (2009) tannins are known for their antimicrobial activity and the growth and enzyme activity of many microorganisms. They may reduce the digestibility of cell walls by binding bacterial enzymes and (or) forming ingestible complexes with cell wall carbohydrates. They also create complex protein. Tannin-protein interactions depend on the structure either of protein or of tannins. Tannins, similarly as essential oils or saponins, exhibit antimicrobial action. However, as with other biologically active compounds, the mechanism of their action depends on the one hand on their chemical structure and on the other hand on the group of microorganisms which it influences.

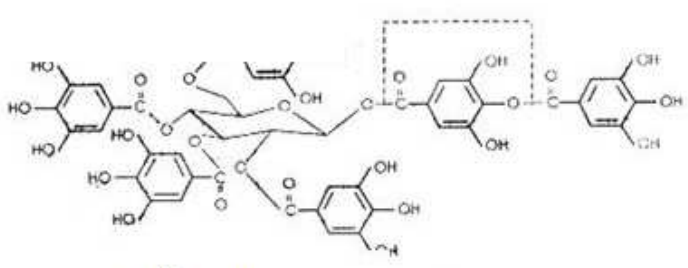

Gallotanin

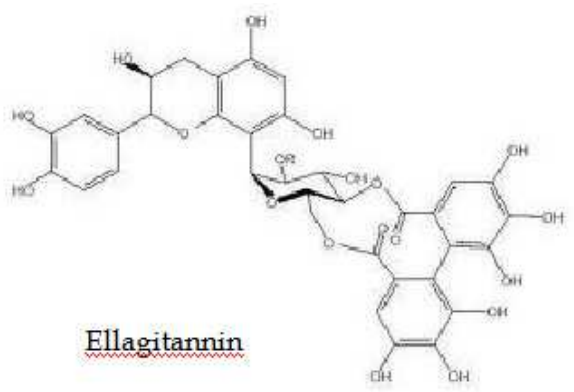

Hexahydroxydiphenic acid<smiles>O=C(O)c1cc(O)c(O)c(O)c1-c1c(C(=O)O)cc(O)c(O)c1O</smiles><smiles>O=C(O)c1cc(O)c(O)c(O)c1</smiles>

Gallic acid<smiles>O=C1Oc2c(O)c(O)cc3c2c(=O)oc2c(O)c(O)cc1c23</smiles>

Ellagic acid

Fig. 2. Structure of hydrolysable tannins (www.ansci.cornell.edu) 


\section{Flavan-3-4, diols}

\section{Proanthocyanidins}

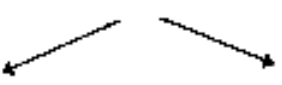

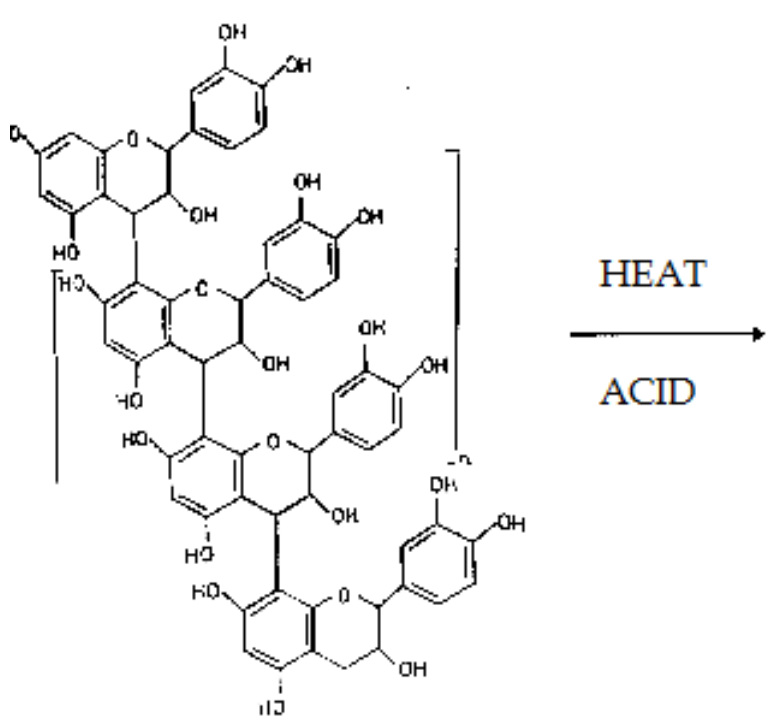

\section{Anthocyanidins}<smiles>Oc1cc(O)c2cc(O)c(-c3ccc(O)c(O)c3)cc2c1</smiles>

Fig. 3. Structure of condensed tannins (www.ansci.cornell.edu)

Thus the applications of biologically active plant origin substances, including tannins, to mitigate enteric ruminal $\mathrm{CH}_{4}$ emissions and ammonia production are becoming increasingly extensive (Szumacher-Strabel \& Cieślak, 2010). Unfortunately, the reduction of methane production through the application of forages containing condensed tannins (CT), recorded in many studies (Woodward et al., 2001; 2002; Hess et al., 2003a; Animut et al., 2008), may have been caused by the negative effect of tannins on the digestibility of nutrients. This results from the fact that tannins exhibit an antinutritional effect. It consist in their ability to form complexes with proteins and sugars, as a result of which the digestibility of nutrients contained in feed is limited, reducing the utilization of nutrients from the feed ration. Another cause of the reduced digestibility may be connected with the reduction of activity of cellulase and xynalase, i.e. enzymes degrading structural carbohydrates (Salawu et al., 1999). However, it needs to be mentioned here that other studies on the effect of tannins on the rumen environment did not show a limitation of activity of cellulolytic bacteria (Animut et al., 2008). Moreover, the amount of tannins in feed exceeding $60 \mathrm{~g} / \mathrm{kg}^{-1}$ gives it a bitter taste, deteriorating palatability and thus reducing feed uptake by animals.

An addition of tannins to feed rations used in the nutrition of ruminants may influence the process of methanogenesis, similarly as in case of other biologically active substances, either indirectly or directly (Tavendale et al., 2005; Bhatta et al., 2009). Indirectly tannins may reduce the populations of microorganisms participating in fermentation processes in the 
rumen environment, and thus reducing the concentration of $\mathrm{H}_{2}$, a necessary substrate for the formation of methane. This action may be also direct on the populations of methanogens, thanks to which methane is formed in the rumen ecosystem. In studies conducted using methanogens commonly found in the rumen environment (Methanobrevibacter ruminantium), a deactivation of these microorganisms was found, which caused a reduction of methanogenesis in the rumen environment (Tavendale et al., 2005). The authors of those studies suggested that a reduced growth of methanogens could have been caused by the bacteriostatic and bactericidal effects of CT. In other studies it was shown that CT has a greater potential to reduce the process of methanogenesis in comparison to hydrolyzing tannins (HT; Bhatta et al., 2009). A team of Tavendale et al. (2005) showed that the reducing action of tannins on the populations of methanogens may depend on the chemical structure of tannins. In their studies they used CT. In other experiments attention was focused on feeds containing both HT and CT, exhibiting a greater potential to reduce methanogenesis than feeds containing only HT (Bhatta et al., 2009). According to those authors, one of the causes of the differences resulting from the effect of HT and CT is connected with the action on the populations of protozoans. However, Śliwiński et al. (2002) stated that extracts containing HT did not have a negative effect on protozoan populations, whereas Leinmúller et al. (1991) showed that HT influences the counts of protozoans, although its action was smaller in comparison to CT, which is consistent with previously cited data (Bhatta et al., 2009). In view of the above, Beauchemin et al. (2007) suggested the use of a CT extract to reduce $\mathrm{CH}_{4}$ emissions, as an alternative to the use of tannin-rich forages. Literature data concerning the limitation of ciliate populations in the rumen, and thus the amount of formed methane in the rumen after the application of tannins, are ambiguous (Patra \& Saxena, 2009; Szumacher-Strabel \& Cieslak, 2010). Most studies indicate that tannins reduce populations of protozoans (Salawu et al., 1999; McSweeney et al., 2001; Patra et al., 2006; Animut et al., 2008). Similar dependencies were shown in studies conducted using CT of leucaena, acacia and eucalyptus (Sallam et al., 2010). Moreover, in another experiment it was shown that CT from leucaena not only reduces the counts of protozoans, but also populations of methanogens, thus significantly reducing the amount of formed methane (Tan et al., 2011). According to Makkar et al. (1995), a reduction of the protozoan population as a result of a tannin addition to feed rations not only causes a limitation of the amount of produced methane, but also influences the scale of synthesis of microbial protein in this environment. However, it needs to be remembered that the reduction of the amount of methane formed in the rumen depends on many factors, including e.g. the amount of applied tannins, administration time of tannin carriers, or animal species given the feed with an addition of tannins (Szumacher-Strabel \& Cieslak, 2010). However, such sources of tannins are being continuously searched for, which while reducing methane production in the rumen would not have a negative effect on the rumen ecosystem. An example of such analyses may be provided by experiments conducted by Monforte-Briceno et al. (2005). Those researchers analyzed 15 plants, tannin carriers, in terms of their antiprotozoal action. However, only three plants turned out to be effective. Other studies determined e.g. the dependence between the content of biologically active compounds (i.e., total phenols, total tannins, condensed tannins and tannin activity using a tannin bioassay) in 17 plant materials and the production of methane. It was shown that among them only 6 (leaves of Rheum undulatum, Vaccinium vitis-idaea, B. crassifolia, Rhus typhina and P. peltatum, and roots of B. 
crassifolia) have considerable potential (i.e., $>25 \%$ ) to decrease enteric methane production from ruminants (Jayanegara et al., 2009). In turn, in another experiment screening unconventional feeds and various supplements for their ruminal methane mitigation potential only a trend towards a reduction of the amount of produced methane (by 15\%) was shown in case of the application of a high-tannin extract from Acacia mearnsii $(50 \mathrm{~g} / \mathrm{kg}$ diet; Staerfl et al., 2010). This points to the fact that researchers searching for an ideal agent reducing the amount of produced methane still face a long way to go before they obtain satisfactory results not only from the scientific, but also practical point of view.

\subsection{Antibiotics growth promoters}

Antibiotic growth promoters (AGP) started to be used in mid fifties of XX century. They are actually applied in United States of America, China and Argentina. AGP were utilized in animal nutrition in Europe until 2006 when the ban on their use (Directive 1831/2003/CEE, European Commission 2003), implemented in 2003 and effective since 1st January 2006, has been introduced. The principal reason for this directive was connected with the increasingly negative attitude of the public to feed additives applied so far. Reports appeared on a dependence between antibiotics used in animal nutrition and growth of antibiotic-resistant bacterial strains, including those pathogenic to humans (Barton, 2000; Hurd, 2005), which was confirmed several years later, when evidence was presented on an increased resistance of certain strains, e.g. Salmonella typihimurium DT104, Campylobacter spp. and Escherichia coli. Until the moment antibiotic growth stimulants were withdrawn, they had been used on a broad scale in order to improve the composition of ruminal microflora, thus eliminating or inhibiting microorganisms and their products (toxins), having a potentially deteriorating effect on digestion processes. The growth stimulating effect, which was caused by subtherapeutic doses of antibiotics in feed rations was discovered in the 1940's, when for the first time a fermentation extract of Streptomyces aureofaciens was applied in feeding chickens. Over the last thirty years a positive effect of AGP was found in terms of increased body weight gains, particularly in the period before weaning, as well as more advantageous feed conversion ratios (Gaskin et al., 2002). Thanks to the effective application of antibiotics in feeds for monogastric animals, as well as in feeding of ruminants, the use of AGP led to advances in this technology, production and practical applications.

Monensin, was the first ionophore antibiotic allowed in animal nutrition by Food and Drug Administration in 1971 (McGuffy et al., 2001). AGP have also potential to decrease green house gasses production and emission to the atmosphere, as well as to decrease the digestive tract pathogens activity. They are active against gram-positive bacteria, protozoa and fungi inhabiting the digestive tract. Also some gram-negative bacteria are sensitive to ionophores. Their utilization may have positive effect on rumen nitrogen metabolism, nitrogen retention and as the consequence may decrease protein degradation and ammonia production and emission. Ionophores reduce ruminal degradation of peptides and deamination of amino acids thus decreasing rumen ammonia production (Hobson \& Stewart, 1997). This lead to increased protein concentration and absorption in the further part of digestive tract and improved feed utilization (McGuffy et al., 2001). It was noticed in in vitro studies that, microbial efficiency expressed per mol ATP $(\mathrm{g} / \mathrm{mol})$ was increased by monensin from 7.8 to 12.6. Moreover, protein conversion ratio, degradability of protein and microbial protein synthesis efficiency were increased and non protein utilization ratio 
decreased in the presence of monensin (Jalč et al., 1992). However ionophore antibiotics are not harmful to methanogens, it is proved that they reduce methane precursors, hydrogen and formate (Hobson \& Stewart, 1997). Ionophores act by interrupting transmembrane movement and intracellular equilibrium of ions in certain classes of bacteria and protozoa (McGuffy et al., 2001; Heydari et al., 2008). Many of them are not selective in acting. The commonly increasing use of antibiotic growth stimulants in the feed rations for animals was caused first of all by an improvement of productivity and a limitation of incidence of certain wide-spread diseases related with the alimentary tract of animals. However, in the early 1990 's the first reports appeared on the potential acquisition of cross immunity by humans towards antibiotics used in animal feeding. The probability of such antibiotic resistance in certain bacteria turned to be slight, but fateful, as in case of e.g. vancomycin. Its long-term use in feeding of slaughter animals caused the development of vancomycin-resistant enterococci. This type of bacteria does not cause any disease in animals, whereas in the human organism it contributes to the development of inflammatory conditions in the urinary system and may cause endocarditis. Moreover, an increased resistance to vancomycin was found for certain bacterial strains pathogenic to humans, such as e.g. Staphylococcus ureus (Van den Bogaard et al., 2000). In view of the presented examples, with the concern for the quality of life and health safety of the general public, and in connection with the ineffectiveness of antibiotic therapy a complete ban was passed on the use of "unnatural" feed additives to feed rations for farm animals in the European Union. The presently increasing consumer awareness has led to the elimination of all non-plant origin compounds added to animal feeds. Today consumers require food to be not only of high health safety quality, but mainly free from any additives, which may potentially lead in the future to an increase in resistance of animal organisms to certain pathogenic bacterial strains. That situation resulted in an intensive development of research on searching and using effective natural compounds displaying similar properties, that were discussed above.

\section{Conclusions}

It can be concluded that it is possible to mitigate rumen methane and ammonia production by modulation of dietary nutrients, however, more studies are needed to determine the impact of particular component, the interaction among components (synergistic and antagonistic reactions) as well as interaction among the dietary nutrients and particular microbial population. Of course, each research should be verified in in vivo condition with mixed ruminal microflora, taking under consideration environmental factors. What is more, studies on compounds found in plants, potentially influencing ruminal metabolism and as a consequence - also the productivity of animals, should not only be strategic, but rather fundamental objectives, making it possible to broaden our knowledge on the interdependencies between animals and the cocktail of phytochemical compounds they consume with feed every day.

\section{References}

Agarwal, N.; Shekhar, C.; Kumar, R.; Chaudhary, L.C.; Kamra, D.N. (2009) Effect of peppermint (Mentha piperita) oil on in vitro methanogenesis and fermentation of feed with buffalo rumen liquor. Anim. Feed Sci. Technol., 148, 321-327 
Animut, G.; Goetsch, A.L.; Puchala, R.; Patra, A.K.; Sahlu, T.; Varel, V.H.; Wells, J. (2008) Methane emission by goats consuming different sources of condensed tannins. Anim. Feed. Sci. Technol., 144, 228-241

Attwood, G.T. \& Reilly K. (1995) Identification of proteolytic rumen bacteria isolated from New Zealand cattle. J. Appl. Bacteriol., 79, 22-29

Ban Salem, H.; Krzeminski, R.; Ferlay, A.; Doreau, M. (1993) Effect of lipid supply on in vivo digestion in cows: comparison of hay and silage diets. Can. J. Anim. Sci., 73, 547-557

Barszcz, M. \& Skomiał, J. (2011) Possibilities of tannins utilization in the protection of animals and human health. Post. Nauk. Roln., 2, 95-110, in Polish

Barton, M.D. (2000) Antibiotic use in animal feed and impact on human Health. Nutr. Res. Rev., 13, 279-299

Beauchemin, K.A.; Kreuzer, M.; O’Mara, F. \& McAllister T.A. (2008) Nutritional management for enteric methane abatement: a review. Aust. J. Experim. Agric., 48, 21-27

Beauchemin, K.A.; McGinn, S.M.; Benchaar,C.; Holtshausen, L. (2009) Crushed sunflower, flax, or canola seeds in lactating dairy cow diets: Effects on methane production, rumen fermentation, and milk production. J. Dairy Sci., 92, 2118-2127

Beauchemin, K.A.; McGinn, S.M.; Martinez, T.F.; McAllister, T.A.; (2007) Use of condensed tannin extract from quebracho trees to reduce methane emissions from cattle. J. Anim. Sci., 85, 1990-1996

Benchaar, C.; Calsamiglia, S.; Chaves, A.V.; Fraser, G.R.; Colombatto, D.; McAllister, T.A.; Beauchemin, K.A.; (2008) A review of plant-derived essential oils in ruminant nutrition and production. Anim. Feed Sci. Technol., 145, 209-228

Benchaar, C. ; Petit, H.V. ; Berthiaume ,R. ; Ouellet, D.R. ; Chiquette, J. ; Chouinard, P.Y. (2007) Effects of essential oils on digestion, ruminal fermentation, rumen microbial populations, milk production, and milk composition in dairy cows fed alfalfa silage or corn silage. J. Dairy Sci., 90, 886-897

Benchaar, C.; Petit, H.V.; Berthiaume, R.; Quellet, D.R.; Chiquitte, J.; Chouinardt, P.Y. (2007) Effects of Essential Oils on Digestion, Ruminal Fermentation, Rumen Microbial Populations, Milk, Production, and Milk Composition in Dairy Cows Fed Alfalfa Silage or Corn Silage. J. Dairy Sci., 90, 886-897

Bhatta, R.; Uyeno, Y.; Tajima, K.; Takenaka, A.; Yabumoto, Y.; Nonaka, I.; Enishi, O.; Kurihara, M. (2009) Difference in the nature of tannins on in vitro ruminal methane and volatile fatty acid production and on methanogenic archaea and protozoal populations. J. Dairy Sci., 92, 5512-5522

Black, P.N. \& DiRusso, C.C. (2003) Transmembrane Movement of Exogenous Long-Chain Fatty Acids: Proteins, Enzymes, and Vectorial Esterification. Microbiol. Molecul. Biol. Rev., 67, 454-472

Boadi, D.; Benchaar, C.; Chiquette, J. Masse, D. (2004) Mitigation strategies to reduce enteric methane emissions from dairy cows: Update review. Can. J. Anim. Sci., 84, 319-335

Broudiscou, L.; Pochet, S.; Poncet, C. (1994) Effect of linseed oil supplementation on feed degradation and microbial synthesis in the rumen of ciliate-free and refaunated sheep. Anim. Feed Sci. Technol. 49, 189-202

Bruel, S. \& Coote, P. (1999) Preservative agents in foods - Mode of action and microbial resistance mechanisms. Int. J.Food Microbiol., Amsterdam, v. 50, p.1-17 
Burt S., (2004) Essentials oils: Their antibacterial properties and potential applications in food-a review. Int. J. Ford Microbiol., 94, 223-253

Busquet, M.; Calsamiglia, S.; Ferret, A.; Kamel, C. (2006) Plant extracts affect in vitro rumen microbial fermentation. J. Dairy Sci., 89, 761-771

Busquet, M.; Calsamiglia, S.; Ferret, S.; Kamel, C. (2005) Screening for the effects of natural plant extracts and secondary plant metabolites on rumen microbial fermentation in continuous culture. Anim. Feed Sci. Technol. 123, 597-613

Calsamigilia, S.; Busquet, M.; Cardozo, P.W.; Castillejos, L.; Ferret, A. (2007) Invited Review: Essential Oils As Modifiers of Rumen Microbal Fermentation J. Dairy Sci., 90, 25802595

Castillejos, L.; Calsamiglia, S.; Ferret, A.; Losa R. (2007) Effects of dose and adaptation time of a specific blend of essential oil compounds on rumen fermentation Anim. Feed Sci. Technol., 132, 186-201

Castillejos, L.; Calsamiglia, S.; Ferret, A. (2006) Effect of essential oils active compounds on rumen microbial fermentation and nutrient flow in in vitro systems. J. Dairy Sci., 89, 2649-2658

Chao, S.C.; Young, D.G. (2000) Screening for inhibitory activity of essential oils on selected bacteria, fungi and viruses. J. Essent. Oil Res., 12, 639-649

Cheeke, P.R. (1999) Actual and potential application of Yucca schidigera and Quillaja saponaria saponins in human and animal nutrition. Proc. Am. Soc. Anim. Sci., pp. 1-10

Cheong, G.W.; Cejka, Z.; Peters, J.; Stetter, K.O.; Baumeister W. (1991) The surface protein layer of Methanoplanus limicola: three-dimensional structure and chemical characterization. System App. Microbiol., 14, 209-27

Cieślak, A.; Kowalczyk, J.; Czauderna, M.; Potkański, A.; Szumacher - Strabel, M. (2010) Enhancing unsaturated fatty acids in ewe's milk by feeding rapeseed or linseed oil. Czech. J. Anim. Sci., 55, 496-504

Cieślak, A.; Miltko, R.; Bełżecki, G.; Szumacher-Strabel, M.; Michałowski, T. (2009b) Rumen ciliates Entodinium caudatum, Eudiplodinium maggii and Diploplastron affine: a potential reservoir of unsaturated fatty acids for the host. Acta Protozool., 48, 335340

Cieślak, A.; Miltko, R.; Bełżecki, G.; Szumacher-Strabel, M.; Potkańki, A.; Kwiatkowska, E.; Michałowski, T. (2006a) Effect of vegetable oils on the methane concentration and population density of the rumen ciliate, Eremoplastron dilobum, grown in vitro. J. Anim. Feed Sci., 15, 15-18

Cieślak, A.; Potkański, A.; Kowalczyk, J.; Szumacher-Strabel, M.; Czaczyk, K.; Gubała, A.; Janicki M. \& Szymankiewicz E. (2005) Methane production in in vitro studies as an effect of different additives to grass silage. J. Anim. Feed Sci., 14, Suppl. 1, 307-310

Cieślak, A.; Potkanski, A.; Szumacher-Strabel M. \& Kowalczyk J. (2004) Blood parameters of lambs fed diets with vegetable oil supplements J. Anim. Feed Sci., 13 Suppl. 2, 21-24

Cieślak, A.; Szumacher-Strabel, M.; Potkański, A.; Kowalczyk J.\& Czauderna M. (2001) The effects of different amounts and types of fat on the extent of C18 unsaturated fatty acid hydrogenation in the rumen of sheep. J. Anim. Feed Sci., 10, Suppl. 2, 123-128

Cieślak, A.; Szumacher-Strabel, M.; Szymankiewicz, E.; Piękniewski, M,; Oleszak, P.; Siwiński, Ł.; Potkański A. (2006b) Coconout oil reduces protozoa amount and methane release during fermentation in a RUSITEC system. J. Anim. Feed Sci., 15, $19-22$ 
Cieślak, A.; Váradyová, Z.; Kišidayová, S.; Szumacher-Strabel M. (2009a) The effects of linoleic acid on the fermentation parameters, population density, and fatty-acid profile of two rumen ciliate cultures, Entodinium caudatum and Diploplastron affine. Acta Protozool., 48, (1) 51-61

Cieślak, A.; Zmora, P.; Nowakowska, A.; Szumacher-Strabel, M. (2009c) Limonene affect rumen methanogenesis inhibiting the methanogens populations. Acta Bioch. Pol., 56, Suppl. 2, 59-60

Cowan, M.M. (1999) Plant products as antimicrobial agent. Clin. Microbiol. Reviews 12, 564582

Cox, S.D.; Mann, C.M.; Markam, J.L. (2001) Interaction between components of the essential oil of Melaleuca alternifolia. J. Appl. Microbiol., 91, 492-49

Crutzen, P.J.; Aselmann, I. \& Seiler W. (1986) Methane Production by Domestic Animals, Wild Ruminants, other Herbivorous Fauna, and Humans. Tullus 33B, pp.271-284

Czerkawski, J.W.; Blaxter, K.L. \& Wainman F.W. (1966) The metabolism of oleic, linoleic, and linolenic acids by sheep with reference to their effects on methane production. Br. J. Nutr., 20, 349 -362

Dohme, F.; Machmüller, A.; Sutter, F.; Kreuzer, M. (2004) Digestive and metabolic utilization of lauric, myristic and stearic acid in cows, and associated effects on milk fat quality. Arch. Anim. Nutr., 58, 99-116

Dohme, F.; Machmüller, A.; Wasserfallen, A.; Kreuzer, M. (2001) Ruminal methanogenesis as influenced by individual fatty acids supplemented to complete ruminant diets. Lett. Appl. Microbiol., 3, 47-51

Dong, Y.; Bea, H.D.; McAllister, T.A.; Mathison, G.W.; Cheng, K.G. (1997) Lipid induced depreession of methane production and digestibility in the artificial rumen system (RUSITEC). Can. J. Anim. Sci., 77, 269-278

Dorman, H.J.D. \& Deans S.G. (2000)Antimicrobial agents from plants: Antibacterial activity of plant volatile oils. J. Appl. Microbiol., 88, 308-316

Eugene, M.; Masse, D.; Chiquette, J.; Benchaar, C. (2008) Meta-analysis on the effect of lipid supplementation on methane production in lactating dairy cows. Can. J. Anim. Sci., $88,331-334$

European Commission (2003) Regulation (EC) No. 1831/2003 of the European Parliament and of the Council of 22 September 2003 on Additives for Use in Animal Nutrition. Off. J. Eur. Union, L268/29-L268/43

FAO - Food and Agriculture Organization of the United Nations (2008) FAOSTAT, Available from http:/ / faostat.fao.org/

Fievez, V.; Dohme, F.; Danneels, M.; Raes, K.; Demeyer, D. (2003) Fish oils as potent rumen methane inhibitors and associated effects on rumen fermentation in vitro and in vivo. Anim. Feed Sci. Technol., 104, 41-58

Finlay, B.J.; Esteban, G.; Clarke, K.J.; Williams, A.G.; Embley, T.M.; Hirt, R.R (1994) Some rumen ciliates have endosymbiotic methanogens. FEMS Microbiol. Lett., 117, 157162

Finlay, B.J.; Esteban, G.; Clarke, K.J.; Williams, A.G.; Embley, T.M.; Hirt, R.R. (1994) Some rumen ciliates have endosymbiotic methanogens. FEMS Microbiol. Lett., 117, 157162

Gaskin, H.R.; Collier C.C.; Anderson, D.B. (2002) Antibiotics as growth promoters mode of action. Anim. Biotechnol., 13, 29-42 
Gershenzon J. \& Croteau R. (1991) Terpenoids. Their Interactions with Secondary Plant Metabolites. Vol. 1. G.A. Rosenthal, M.R. Berenbaum, Academic Press, San Diego, CA. pp. $165-219$

Giger-Reverdin, S.; Morand-Fehr, P.; Tran, G. (2003) Literature survey of the influence of dietary fat composition on methane production in dairy cattle. Livest. Prod. Sci., 82, 73-79

Goel, G.; Makkar, H.P.S.; Becker K. (2008) Changes in microbial community structure, methanogenesis and rumen fermentation in response to saponin-rich fractions from different plant materials. J. Appl. Microbiol., 105, 770-777

Graeme, T.; Attwood, G.T.; Klieve, A.V.; Ouwerkerk, D.; Patel, B.K.C. (1998) Ammoniahyperproducing bacteria from New Zealand ruminants. Appl. Environ. Microbiol., 64, 1796-1804

Grant, R.J. \& Weidner, S.J. (1992) Effect of fat from whole soyabeans on performance of dairy cows fed rations differing in fiber level and particle size. J. Dairy Sci., 75, 2742 $-2751$

Greathead, H. (2003) Plants and plant extracts for improving animal productivity. Proc. Nutr. Soc., 62, 279-290

Griffin, S.G.; Wyllie, S.G.; Markham, J.L.; Leach D.N. (1999) The role of structure and molecular properties of terpenoids in determining their antimicrobial activity. Flavour Fragr. J., 14, 322-332

Guo, Y.Q.; Liu, J.X.; Lu, Y.; Zhu, W.Y.; Denman, S.E.; McSweeney, C.S. (2008) Effect of tea saponin on methanogenesis, microbial community structure and expression of mcrA gene, in cultures of rumen microorganisms. Lett. Appl. Microbiol., 47, 421-426

Hafenbradl, D.; Keller, M.; Stetter, K.O. (1996) Lipid analysis of Methanopyrus kandleri. FEMS Microbiol. Lett. 136, 99-202

Hart, K.J.; Yáñez-Ruiz, D.R.; Duval, S.M.; McEwan, N.R.; Newbold, C.J. (2008) Plant extracts to manipulate rumen fermentation. Anim. Feed Sci. Technol., 147 (1-3), 8-35

Hearn, E.M.; Patel, D.R.; Lepore, B.W.; Indic, M.; van Berg, B. (2009) Transmembrane passage of hydrophobic compounds through a protein channel wall. Nature, 458, 367-70

Hegarty, R. S. (1999a) Mechanisms for competitively reducing ruminal methanogenesis. Aust. J. Agric. Res. 50, 1299-1305

Henderson, C. (1973) The effects of fatty acids on pure cultures of rumen bacteria. J. Agric. Sci., 81, 107-112

Hess, H.D.; Kreuzer, M.; Diaz, T.E.; Lascano, C.E.; Carulla, J.E.; Soliva, C.R.; Machmúller, A. (2003a) Saponin rich tropical fruits affect fermentation and methanogenesis in faunated and defaunated rumen fluid. Anim. Feed Sci. Technol., 109, 79-94

Hess, H.D.; Monsalve, L.M.; Lascano, C.E.; Carulla, J.E.; Diaz, T.E.; Kreuzer, M. (2003b) Supplementation of a tropical grass diet with forage legumes and Sapindus saponaria fruits: effects on in vitro ruminal nitrogen turnover and methanogenesis. Aust. J. Agric. Res., 54, 703-713

Heydari, K.H.; Dabiri, N.; Fayazi, J.; Roshanfekr, H. (2008) Effect of ionophores monensin and lasalocid on performance and carcass characteristics in fattening Arabi lambs. Pak. J. Nutr., 7, 81-84

Hilpert, R.; Winter, J.; Hammes, W.; Kandler O. (1981) The sensitivity of archaebacteria. Zentralbl. Bacteriol. Microbiol. Hyg. Abt. 1 Orig Reihe C3, 228-244 
Hristov, A.N.; Ivan, M.; Neill, L.; McAllister, T. A. (2003) A survey of potential bioactive agents for reducing protozoal activity in vitro. Anim. Feed Sci. Technol., 105, 163-184

Hristov, A.M.; Ivan, M.; McAlister, T.A. (2004) In vitro effects of individual fatty acids on protozoal numbers and on fermentation products in ruminal fluid from cattle fed a high-concentrate, barley-based diet. J. Anim. Sci., 82, 2693-2704

Hristov, A.N.; Ropp, J.K.; Zaman, S.; Melgar, A. (2008) Effects of essential oils on in vitro ruminal fermentation and ammonia release. Anim. Feed Sci. Tech., 144, 55-64

Hristov, N.A.; McAllister, T.A.; Van Herk, F.H.; Cheng, K.J.; Newbold, C.J.; Cheeke, P.R. (1999) Effect of Yucca schidigera on ruminal fermentation and nutrient digestion in heifers. J. Anim. Sci., 77, 2554-2563

Hu, W.L.; Guo, Y.Q.; Liu, J.X.; Wu, Y.M.; Ye J.A. (2005) Tea saponins affect methanogenesis and fermentation in faunated and defaunated rumen in vitro RPT system. J. Zhejing Univ. Sci., 6B, 787-792

Hurd, H.S. (2005) Can antibiotic use in ford animals actually reduce consumer risk? Food Safety Asia, pp. 120-122

Hvelplund, T.; Stigsen, P.; Moller, P. D. \& Jensen, K. (1978) Propionic acid production rate in the bovine rumen after feeding untreated and sodium hydroxide-treated straw. $Z$. Tierphys. Tierernahr. Fuutermittelkde. 40, 183 - 190

IPCC (Intergovernmental Panel on Climate change) (2007) The Physical Science Basis, Contribution of Working Group I to the Fourth, Available from http://www.ipcc.ch/publications_and_data/publications_ipcc

Ipharraguerre, I. R. \& Clark, J. H. 2003. Usefulness of ionophores for lactating dairy cows: A review. Anim. Feed Sci. Technol., 106, 39-57

Islam, M. R. \& Begum J. (1997) Short review of global methane situation and of facilities to reduce in ruminants in third world countries. AJAS 10 (No.2), 157-163

Ivan, M.; Mir, P.S.; Koeing, K.M.; Rode, L.M.; Neill, L.; Entz, T.; Mir, Z. (2001) Effects of dietary sunflower seed oil on rumen protozoa population and tissue concentration of conjugated linoleic acid in sheep. Small Rumin. Res., 41, 215-227

Jalč, D.; Baran, M.; Vendrák T. \& Siroka P. (1992) Effect of Monensin on Fermentation of Hay and Wheat Bran Investigated by the Rumen Simulation Technique (RUSITEC) Arch. für Tiererna. 42, 2, 153-158

Jalč, D.; Cieślak, A.; Potkański, A.; Szumacher-Strabel M. \& Kowalczyk J. (2006c) The effect of different oils and diets on methane release in an artificial rumen (Rusitec). J. Anim. Feed Sci., 15, Suppl. 1, 149-152

Jalč, D.; Potkański, A.; Szumacher-Strabel, M.; Kowalczyk J. \& Cieślak A. (2006a) The effect of a high concentrate diet and different fat sources on rumen fermentation in vitro. J. Anim. Feed Sci., 15, Suppl. 1, 137-140

Jalč, D.; Potkański, A.; Szumacher-Strabel, M.; Kowalczyk J. \& Cieślak A. (2006b) The effect of a high forage diet and different oil blends on rumen fermentation in vitro. J. Anim. Feed Sci., 15, Suppl. 1, 141-144

Jalč, D.; Potkański, A.; Szumacher-Strabel, M.; Kowalczyk J. \& Cieślak A. (2006d) The effect of a forage diet and different fat sources on rumen fermentation in vitro. J. Anim. Feed Sci., 15, Suppl. 1, 129-134

Jayanegara, A,; Togtokhbayar, N.; Makkar, H.P.S.; Becker, K. (2009) Tannins determined by various methods as predictors of methane production reduction potential of plants by an in vitro rumen fermentation system. Anim. Feed Sci. Technol., 150, 230-237 
Jensen, K. \& Wolstrup P. (1977) Effect of feeding frequency of fermentation pattern and microbial activity in the bovine rumen. Act Vet. Scand., 18, 108-121

Joblin, K.N.; Matsui, H.; Naylor, G.E.; Ushida K. (2002) Degradation of fresh ryegrass by methanogenic co-culture of ruminal fungi grown in the presence or absence of Fibrobacter succinogenes. Curr. Microbiol., 45, 46-53

Johnson, K.A. \& Johnson, D.E. (1995) Methane emissions from cattle. J. Anim. Sci. 73, 24832492

Jones, W.J.; Nagle, D.P.Jr. \& Whitman W.P. (1987): Methanogens and the diversity of archaebacteria. Microbiol. Rev., 51, 135-177

Jonson, D.E.\& Ward G.M. (1996) Estimates of animal methane emissions. Environmental Monitoring and Assessment 42, pp. 133-141. Kluwer Academic Publishers. Printed in the Netherlands

Jordan, E.; Kenny, D.; Hawkins, M.; Malone, R.; Lovett, D.K. \& O'Mara F.P. (2006) Effect of refined soy oil or whole soybeans on intake, methane output, and performance of young bulls. J. Anim. Sci., 84, 2418-2425

Kamel, C.; Greathead, H.M.R.; Tejido, M.L.; Ranilla, M.J.; Carro, M.D. (2008) Effects of allicin and diallyldisulfideon in vitro rumen fermentation of a mixed diet. Anim. Feed Sci. Technol., 145, 351-363

Kamra, D.N. (2005) Rumen microbial system, Curr. Sci., 89 (1), 124-135

Karnati, S.K.R.; Yu, Z.; Firkins, J.L. (2009) Investigating unsaturated fat, monensin, or bromoethanesulfonate in continuous cultures retaining ruminal protozoa. II. Interaction of treatment and presence of protozoa on prokaryotic communities. J. Dairy Sci., 92, 3861-3873

Kaufmann, W.; Hagemeister, H. \& Dirksen G. (1980) Adaptation to changes in dietary composition, level and frequency of feeding. In: Y. Ruckebusch and P Thivend (Eds.). Digestive Physiology and Metabolism in Ruminants. MTP Press, Lancaster, England. pp. 587-602

Khalil, M. A. K. (2000): Atmospheric methane: an introduction. In Atmospheric Methane: Its Role in the Global Environment, pp.1-8. Springer-Verlag, Berlin, Germany

Kirchgesser, M.; Windisch, W.; Muller, H.L. (1995) Nutrional factors for the quantification of methane production. In: Engelhardt W. V., Leonhard-Marek S., Breves G., Giesecke D. (Eds.) Ruminant physiology: Digestion, metabolism, growth and reproduction, Proceedings of the Eighth International Symposium on Ruminant Physiology, Ferdinad Enke Verlag, Stuttgart, pp. 333-348

Kisidayova, S.; Mihalikova, K.; Varadyova, Z.; Potkański, A.; Szumacher-Strabel, M.; Cieślak, A.; Certik, M.; Jalč, D. (2006) Effect of microbial oil, evening primrose oil and borage oil on rumen ciliate population in artificial rumen (Rusitec) J. Anim. Feed Sci., 15, 153-156

Kisidayova, S.; Varyadova, Z.; Michałowski, T.; Newbold, C.J. (2005) Regeneration of cryoresistance of in vitro rumen ciliate cultures. Cryobiology, 51, 76-84

Kisidayova, S.; Varyadova, Z.; Zelenak, I.; Siroka P. (2000) Methanogenesis in rumen ciliate cultures of Entodinium caudatum and Epidinium ecaudatum after long-term cultivation in a chemically defined medium. Folia Microbiol., 45, 269-274

Kowalczyk, J.; Orskov, E.R.; Robinson, J.J.; Stewart, C.S. (1977) Effects of fat supplementation on voluntary food intake and rumen metabolism in sheep. Brit $J$. Nutr., 37, 251 
Kowalik, B.; Pająk, J.J.; Skomiał, J. (2009) The effect of tannins on processes in the rumen. Post. Nauk Roln., 1, 91-102

Lana, R. P.; Russell, J. B.; Van Amburgh M. E. (1998) The role of pH in regulating ruminal methane and ammonia production. J. Anim. Sci., 76, 2190-2196

Laureles, L.R.; Rodriguez, F.M.; Reano, C.E.; Santos, G.A.; Laurena, A.C.; Mendoza, E.M. (2002) Variability in fatty acid and triacylglycerol composition of the oil of coconut (Cocos nucifera L.) hybrids and their parentals. J. Agric. Food Chem., 50, 1581-1586

Lloyd, D.; Williams, A.G.; Amann, R.; Hayes, A.J.; Durrant, L.; Ralphs, J.R. (1996) Intracellular prokaryotes in rumen ciliate protozoa: detection by confocal laser scanning microscopy after in situ hybridization with fluorescent $16 \mathrm{~S}$ rRNA probes. Europ. J. Protist., 32, 523-531

Machmuller, A. \& Kreuzer M. (1999) Methane suppression by coconut oil and associated effects on nutrient and energy balance in sheep. Can. J. Anim. Sci., 79, 65-72

Machmuller, A. (2006) Medium-chain fatty acids and their potential to reduce methanogenesis in domestic ruminants. Agr. Ecosyst. Environ., 112,107-114

Machmuller, A.; Solva, C.R.; Kreuzer, M. (2003) Effect of coconut oil and defaunation treatment on methanogenesis in sheep. Reprod. Nutr. Dev., 43, 41-55

Maczulak, A.E.; Dehority, B.A.; Palmquist, D.L. (1981) Effects of long-chain fatty acids on growth of rumen bacteria. Appl. Environ. Microbiol., 42, 856-862

Maia, M.R.G.; Chaudhary, L.C.; Figueres, L. \& Wallace, R.J. (2007) Metabolism of polyunsaturated fatty acids and their toxicity to the microflora of the rumen. Antonie Van Leeuwenhoek, 91, 303-314

Makkar, H.P.S. \& Becker K. (1997) Degradation of Quillaja saponins by mixed culture of rumen microbes. Lett. Appl. Microbiol., 25, 243-245

Mao, H-L.; Wang, J-K.; Zhou, Y-Y.; Liu, J-X. (2010) Effects of addition of tea saponins and soybean oil on methane production, fermentation and microbial population in the rumen of growing lambs. Livest. Sci., 129, 56-62

Martin, C.; Morgavi, D.P.; Doreau, M.; (2010) Methane mitigation in ruminants: from microbe to the farm scale. Anim., 4:3, 351-365

Martin, C.; Rouel, J.; Jouany, J.P.; Doreau, M. \& Chilliard, Y. (2008) Methane output and diet digestibility in response to feeding dairy cows crude linseed, extruded linseed, or linseed oil. J. Anim. Sci., 86, 2642-2650

Martin, S.A. \& Jenkins, T.C. (2002) Factors affecting conjugated linoleic acid and trans C18:1 fatty acid production by mixed ruminal bacteria. J. Anim. Sci., 80, 3347-3352

Matsumoto, M.; Kobayashi, T.; Takenaka, A.; Itabashi, H. (1991) Defaunation effects of medium-chain fatty acids and their derivatives on goat rumen protozoa. J. Gen. Appl. Microbiol. 37, 439-445

McAllister, T.A.; Okine, E.K.; Mathison, G.W. \& Cheng K. J. (1996) Dietary, environmental and microbiological aspects of methane production in ruminants. Can. J. Anim. Sci., 76, 231-243

McGuffy, R.K.; Richardson, L.F.; Wilkinson, J.I.D. (2001) Ionophore for dairy cattle: Current status and future outlook. J. Dairy Sci., 84 (E. Suppl.), E194-E203

Miles, C.O.; Wilkins, A.L.; Munday, S.C.; Holland, P.T.; Smith, B.L.; Lancaster, M.J.; Embling, P.P. (1992) Identification of the calcium salt of epismilagenin beta-Dglucuronide in the bile crystals of sheep affected by Panicum-dichotomiflorum and Panicum-schinzii toxicoses. J. Agric. Food Chem., 40, 1606-1609 
Monforte-Briceno, G.E.; Sandoval-Castro, C.A.; Ramirez-Aviles, L.; Capetillo-Leal, C.M. (2005) Defaunating capacity of tropical fodder trees: effects of polyethylene glycol and its relationship to in vitro gas production. Anim. Feed. Sci. Technol., 123-124, 313-327

Monteny, G.J.; Bannink, A. Chadwick D. (2006) Greenhouse gas abatement strategies for animal husbandry. Agric. Ecosyst. Environ., 112, 163-170

Morvan, B.; Bonnemoy, F.; Fonty, G.; Gouet P. (1996) Quantitative determination of H2utilizing acetogenic and sulfate-reducing bacteria and methanogenic archaea from digestive track of different mammals. Curr. Microbiol., 32, 129-133

Morvan, B.; Dore, J.; Rieulesme, F.; Foucat, L.; Fonty, G.; Gouet, P. (1994) Establishment of hydrogen-utilizing bacteria in the rumen of the newborn lamb. FEMS Microbiol. Lett., 117, 249-256

Moss, A. R.; Deaville, E. R. \& Givens, D. I. (1994) Effect of supplementing grass silage with sugar beet feed on methane production by sheep. Proc. Brit. Soc. Anim. Prod., Paper No. 53

Moss, A.R.; Jouany, J.P.; Newbold, C.J. (2000) Methane productions by ruminants: its contribution to global warming. Annal Zootech., 49, 231-253

Muetzel, S.; Hoffmann, E.M.; Becker, K. (2003) Supplementation of barley straw with Sesbania pachcarpa leaves in vitro: effects on fermentation variables and rumen microbial concentration structure quantified by ribosomal RNA-targeted probes. Br. J. Nutr., 89, 445-453

Nakashimada, Y.; Srinivasan, K.; Murakami, M.; Nishio N. (2000) Direct conversion of cellulose to methane by anaerobic fungus Neocallimastix frontalis and defined methanogens. Biotech. Lett., 22, 223-227

Newbold, C.J.; ElHassan, S.M.; Wang, J.; Ortega, M.E.; Wallace, R.J. (1997) Influence of foliage from African multipurpose trees on activity of rumen protozoa and bacteria. Br. J. Nutr., 78, 237-249

Newbold, C.J.; Lassalas, B. \& Jouany, J.P. (1995) The importance of methanogens associated with ciliate protozoa in ruminal methane production in vitro. Lett. Appl. Microbiol., $21,230-234$

Odenyo, A.A.; Osuji, P.O.; Karanfil, O. (1997) Effect of multipurpose tree (MPT) supplements on ruminal ciliate protozoa. Anim. Feed Sci. Technol., 67, 169-180

Oleszek, W.A. (2002) Chromatographic determination of plant saponins. J. Chromatogr., A 967, 147-162

Palmquist, D. L. \& Jenkins T.C. (1980) Fat in lactation rations: review. J. Dairy Sci. 63, 1 - 14

Palmquist, D.L. (1994) The role of dietary fats in efficiency of ruminants. American Institute of Nutrition

Patra, A.K.; Kamra, D.N.; Agarwal, N. (2006) Effect of plant extracts on in vitro methanogenesis, enzyme activities and fermentation of feed in rumen liquor of buffalo. Anim. Feed. Sci. Technol., 128, 276-291

Patra, A.K.; Saxena, J. (2009) Dietary phytochemicals as rumen modifiers: a review of the effects on microbial populations. Antonie van Leeuwenhoek, 96, 369-375

Paustian, K.; Antle, M.; Sheehan, J.; Eldor; P. (2006) Agriculture's Role in Greenhouse Gas Mitigation. Washington, DC: Pew Center on Global Climate Change 
Pen, B.; Sar, C.; Mwenya, B.; Kuwaki, K.; Morikawa, R.; Takahashi, J. (2006) Effects of Yucca schidigera and Quillaja saponaria extracts on in vitro ruminal fermentation and methane emission. Anim. Feed Sci. Technol., 129, 175-186

Pers-Kamczyc, E.; Zmora, P.; CieślakA. \& Szumacher-Strabel M. (2011) Development of nucleic acid based techniques and possibilities of their application to rumen microbial ecology research J. Anim. Feed Sci., 20, 315-337

Place, S.E. \& Mitloehner F.M. (2010) Invited review: Contemporary environmental issues: A review of the dairy industry's role in climate change and air quality and the potential of mitigation through improved production efficiency. J. Dairy Sci., 93, 3407-3416

Plascencia, A.; Estrada, M. \& Zinn, R.A. (1999) Influence of Free Fatty Acids Content on the Feeding Value of Yellow Grease in Finishing Diets for Feedlot Cattle. J. Anim. Sci., $77,2603-2609$

Potkański, A.; Szumacher-Strabel, M,; Cieślak A. (2009) Effect of rapeseed and fish oil blend supplementation to dairy cows summer feeding on rumen parameters and milk fatty acid profile. Anim. Sci. Pap. Rep., 27, 83-93

Regensbogenova, M.; Kisidayova, S.; Michalowski, T.; Javorsky, P.; Moon-Van Der Staay, G.W.M.; Moon-Van Der Staay, S.Y.; Hackstein, J.H.P.; McEwan, N.R.; Jouany, J.P.; Newbold, J.C.; Pristas P. (2004b) Rapid Identification of Rumen Protozoa by Restriction Analysis of Amplified 18S rRNA Gene. Acta Protozool., 43, 219 - 224

Regensbogenova, M.; McEwan, N.R.; Javorsky, P.; Kisidayova, S.; Michalowski, T.; Newbold, C.J.; Hackstein, J.H.P.; Pristas P. (2004a) A re-appraisal of the diversity of the methanogens associated with the rumen ciliates. FEMS Microbiol. Lett., 238, 307313

Russel J. B. (1998) The importance of $\mathrm{pH}$ in the regulation of ruminal acetate to propionate ratio and methane production in vitro. J. Dairy Sci., 81, 3222-3230

Russell, M.J.; Hall, A.J.; Cairns-Smith, A.G. \& Braterman P.S. (1988) Submarine hot springs and the origin of life. Nature, 336,117

Salawu, M.B.; Acamovic, T.; Stewart ,C.S.; Hovell, F.D.; De, B. (1999) Effects of feeding quebracho tannin diets, with or without a dietary modifier, on rumen function in sheep. Anim. Sci., 69, 265-274

Scott A. M. (2002) Basic of rumen microbiology. Course materials 21-24.10.2002. Poznań, Poland.

Shin, E.C.; Choi, B.R.; Lim, W.J.; Hong, S.Y.; An, C.L.; Cho, K.M.; Kim, Y.K.; An, J.M.; Kang, J.M.; Lee, S.S.; Kim, H.; Yun, H.D. (2004) Phylogenetic analysis of archaea in three fractions of cow rumen based on the 16S rDNA sequence. Anaerobe, 10, 313-319

Skillamn, L.C.; Evans, P.N.; Stromp, C.; Joblin, K.N. (2006) 16 S ribosomal DNA-directed PCR primers for ruminal methanogens and identification of methanogens colonizing young lambs. Anaerobe 10, 277-285

Śliwiński, B.; Kreuzer, M.; Wettstein, H.R.; Machmüller, A. (2002) Rumen fermentation and nitrogen balance of lambs fed diets containing plant extracts rich in tannins and saponins, and associated emission of nitrogen and methane. Arch. Anim. Nutr., 56, 379-392

Smith-Palmer, A.; Stewart, J.; Fyfe, L. (1998) Antimicrobial properties of plant essentials oils and essence against five important food-borne pathogens. Lett. Appl. Microbial., 26, $118-122$ 
Soliva, C.R.; Hindrichsen, I.K.; Meile, L.; Kreuzer, M.; Machmüller, A. (2003) Effects of mixtures of lauric and myristic acid on rumen methanogens and methanogenesis in vitro. Lett. App. Microbiol., 37, 35-9

Soliva, C.R.; Meile, L,; Cieślak, A.; Kreuzer, M., Machmuller, A. (2004a) Long-term Rusitec study on the interactions of dietary lauric and miristic acid supplementation in suppressing ruminal methanogenesis Br. J. Nutr., 92, 689-700

Soliva, C.R.; Meile, L,; Hindrichsen, I.K,; Kreuzer, M., Machmuller, A. (2004b) Myristic acid supports the immediate inhibitory effect of lauric acid on ruminal methanogens and methane release. Anaerobe, 10, 269-276

Sparg, S. G.; Light, M. E.; van Staden, J. (2004) Biological activities and distribution of plant saponins. J. Ethnoph., 94, 219-243

Staerfl, S.M.; Kreuzer M. \& Soliva C.R. (2010) In vitro screening of unconventional feeds and various natural supplements for their ruminal methane mitigation potential when included in a maize-silage based diet J. Anim. Feed Sci., 19, 651-664

Steinfeld, H.; Gerber, P.; Wassenaar, T.; Castel, V.; Rosales, M.; de Haan, C. (2006) Livestock's Long Shadow: Environmental Issues and Options. Rome: Food and Agriculture Organization of the United Nations.

Stewart, C.S. \& Bryant M.P. (1988) The rumen bacteria. W: Barnes E.M., Mead G.C. Anaerobic bacteria in habitats other than man. Palo Alto, CA Blackwell Scientific Publications, pp. 21-75

Stewart, C.S.; Flint, H.J.; Bryant M.P. (1997) The rumen bacteria. W: Hobson P.N., Stewart C.S. The Rumen Microbial Ecosystem. London Blackie Academic \& Professional, pp. $10-72$

Sutton, J.D.; Hart, I.C.; Broster, W.H.; Elliott R.J. \& Schuller E. (1986) Feeding frequency for lactating dairy cows: effects on rumen fermentation and blood metabolites and hormones. Brit. J. Nutr., 56, 181-192

Szumacher - Strabel, M. \& Cieślak, A. (2010) Potential of phytofactors to mitigate rumen ammonia and methane production J. Anim. Feed Sci., 19, 3, 319-337

Szumacher-Strabel, M.; Cieślak, A.; Potkański, A,; Kowalczyk J. \& Czauderna M. (2001a) The effects of different amounts and types of fat on rumen microbial protein synthesis in sheep. J. Anim. Feed Sci., 10, Suppl. 2, 97-101

Szumacher-Strabel, M.; Cieślak, A.; Nowakowska A. (2009a) Effect of oils rich in linoleic acid on in vitro rumen fermentation parameters of sheep, goats and dairy cows. $J$. Anim. Feed Sci., 18, 3, 440-452

Szumacher-Strabel, M.; Cieślak, A.; Nowakowska, A.; Potkański, A. (2009b) Feeding plant and fish oils to improve polyunsaturated fat concentrations in intramuscular, perirenal and subcutaneous lambs' fat. Schriftenreihe der Deutschen Gesellschaft Für Züchtungskunde, 81, (2), 133-140

Szumacher-Strabel, M.; Cieślak, A.; Zmora, A.; Pers-Kamczyc, E.; Bielińska, S.; Stanisz, M. \& Wójtowski, J. (2011b) Camelina sativa cake improved unsaturated fatty acids in ewe's milk J. Sci. Food Agric., 91, 2031-2037

Szumacher-Strabel, M.; Martin, S.A.; Potkański, A.; Cieślak, A.; Kowalczyk, J. (2004) Changes in fermentation processes as the effect of vegetable oil supplementation in in vitro studies. J. Anim. Feed Sci., 13, 215-218 
Szumacher-Strabel, M.; Nowakowska, A.; Zmora, P.; Cieślak, A. (2009c) Essentials oils and secondary plant metabolites in dairy cow feeding. Acta Bioch. Pol., 56, Suppl. 2, 5758

Szumacher-Strabel, M.; Potkański, A.; Cieślak, A.; Kowalczyk J. \& Czauderna M. (2001c) The effects of different amounts and types of fat on metabolites in the rumen of sheep. J. Anim. Feed Sci., 10, Suppl. 2, 91-96

Szumacher-Strabel, M.; Potkański, A.; Cieślak, A.; Kowalczyk J. \& Czauderna M. (2001b) The effects of different amounts and types of fat on the level of conjugated linoleic acid in the meat and milk of sheep. J. Anim. Feed Sci., 10, Suppl. 2, 103-108

Szumacher-Strabel, M.; Zmora, P.; Roj, E.; Stochmal, A.; Pers-Kamczyc, E.; Urbańczyk, A.; Oleszek, W.; Lechniak, D. \& Cieślak A. (2011a) The potential of the wild dog rose (Rosa canina) to mitigate in vitro rumen methane production. J. Anim. Feed Sci. 20, 285-299

Tackett, V.L.; Bertrand, T.C.; Jenkins, T.C.; Pardue, F.E. \& Grimes L.W. (1996) Interaction of dietary fat and acid detergent fiber diets of lactating dairy cows. J. Dairy Sci., 79, 270-275

Tajima, K.; Nagamine, T.; Matsui, H.; Nakamura, M.; Animov, R.I. (2001) Phylogenetic analysis of archaeal 16S rRNA libraries from the rumen suggests the existence of a novel group of archaea not associated with known methanogens. FEMS Microbiol. Lett., 200, 67-72

Tavendale, M.H.; Meagher, L.P.; Pacheco ,D.; Walter, N.; Attwood, G.T.; Sivakumaran, S. (2005) Methane production from in vitro rumen incubations with Lotus pedunculatus and Medicago sativa, and effects of extractable condensed tannin fractions on methanogenesis. Anim. Feed Sci. Technol., 123-124, 403-419

Teferedegne, B. (2000) New perspectives on the use of tropical plants to improve ruminant nutrition. Proc. Nutr. Soc., 59, 209-214

Teferedegne, B.; McIntosh, F.; Osuji, P.O.; Odenyo, A.; Wallace, R.J.; Newbold, C.J. (1999) Influence of foliage from different accessions of the sub-tropical leguminous tree, Sesbania sesban, on ruminal protozoa in Ethiopian and Scottish sheep. Anim. Feed Sci. Technol., 78, 11-20

Topping, J.C. (2007) Study by NASA and University Scientists Shows World Temperature Reaching a Level Not Seen in Thousands of Years and Raises Grave Concern of Irreparable Harm, Available from

http://www.climate.org/2002/programs/washington_summit_temperature_rise.

USDA (2011) U.S. Agriculture and Forestry Greenhouse Gas Inventory: 1990-2008. Washington, DC: U.S. Department of Agriculture. Technical Bulletin No. 1930, pp. 159

Ushida, K. \& Jouany, J. P., (1996) Methane production associated with rumen-ciliated protozoa and its effect on protozoan activity. Lett. Appl. Microbiol., 23, 129-132

Van den Bogaard, A.E.; Bruinsma, N.; Stalberingh, E.E. (2000) The effect of banning avoporacin on VRE carriage in the Netherlands. J. Antimicrob. Chemother., 46, 146147

Van Kessel, J.S. \& Russel J.B. (1995) The effect of $\mathrm{pH}$ on in vitro methane production from ruminal bacteria. Proc. Conf. Rum. Funct., 23, 7-29

Van Nevel, C.J. \& Demeyer D.I. (1996) Control of rumen methanogenesis. Environm. Monitor. Assessm., 42, 73-97 
Van Soest, P. J. (1982) Nutritional ecology of the ruminant. Corvallis, Oregon. Books Inc.

Van Soest, P. J. (1994) Nutritional ecology of the ruminant (2nd ed.). Ithaca NY Cornell Univ. Press

Varadyova, Z.; Kišidayova, S.; Siroka, P.; Jalč, D. (2007): Fatty acid profiles of rumen fluid from sheep fed diets supplemented with various oils and effect on the rumen ciliate population. Czech. J. Anim. Sci., 52, 399-406

Vincken, J.P.; Heng, L.; de Groot, A.; Gruppen, H. (2007) Saponins, classification and occurrence in the plant kingdom. Phytochem., 68, 275-297

Vogels, G.D.; Hoppe, W.F.; Stumm C.K. (1980) Association of methanogenic bacteria with rumen ciliates. Appl. Environ. Microbiol., 47, 219-221

Wallace, R.J.; Arthaud, L.; Newbold, C.J. (1994) Influence of Yucca-schidigera extract on ruminal ammonia concentrations and ruminal microorganisms. Appl. Environ. Microbiol., 60, 1762-1767

Wang, C.J.; Wang, S.P.; Zhou, H. (2009) Influences of flavomycin, ropadiar, and saponin on nutrient digestibility, rumen fermentation, and methane emission from sheep. Anim. Feed Sci. Technol., 148, 157-166

Wang, X.F.; Mao, S.Y.; Liu, J.H.; Zhang, L.L.; Cheng, Y.F.; Jin W. \& Zhu W.Y. (2011) Effect of yucca schidigera extract on ruminal fermentation and mathonogens in vitro J. Anim. Feed Sci., 20, 259-271

Wang, Y.X.; McAllister, T.A.; Newbold, C.J.; Rode, L.M.; Cheeke, K.J. (1998) Effects of Yucca schidigera extract on fermentation and degradation of steroidal saponins in the rumen simulation technique (RUSITEC). Anim. Feed Sci. Technol., 74, 143-153

Wang, Y.X.; McAllister, T.A.; Yanke, L.J.; Xu, Z.J.; Cheeke, P.R.; Cheng, K.J. (2000) In vitro effects of steroidal saponins from Yucca schidigera extract on rumen microbial protein synthesis and ruminal fermentation. J. Sci. Food Agric., 80, 2114-2122

Wettstein, H. R.; Machmüller, A; Kreuzer, M. (2000) Effects of raw and modified canola lecithin compared to canola oil, canola seed and soy lecithin on ruminal fermentation measured with rumen simulation technique. Anim. Feed Sci. Technol., 85, 153-169

Williams, A.G. \& Coleman, G.S. (1988) The rumen protozoa. W: Hobson P.N. The Rumen Microbial Ecosystem. London Elsevier Applied Sciences. pp. 77-128

Williams, A.G.; Joblin, K.N.; Fonty, G. (1995) Interactions between the rumen chytrid fungi and other microorganisms. W: Mounffort D.O., Orpin C.G. Anaerobic Fungi: Biology, Ecology and Function. New York Marcel Dekker

Wina, E.; Muetzel, S.; Becker, K. (2006) The dynamics of major fibrolytic microbes and enzyme activity in the rumen in response to short- and ling-term feeding of Sapindus rarak saponins. J. Appl. Microbiol., 100, 114-122

Wina, E.; Muetzel, S.; Hoffmann, E.; Makkar, H.P.S.; Becker, K. (2005) Saponins containing methanol extract of Sapindus rarak affect microbial fermentation, microbial activity and microbial community structure in vitro. Anim. Feed Sci. Technol., 121, 159-174

Wolin, M.J. \& Miller, T.L. (1988) Microbe-microbe interactions. W: Hobson P.N., The rumen microbial ecosystem. New York Elsevier Science Publishers, pp. 343-359

Wolin, M.J.; Miller, C.; Stewart C.J. (1997) Microbe-microbe interactions. W: Hobson P.N., Stewart C.J. The Rumen Microbial Ecosystem. London Blackie Academic \& Professional, pp. 467-491 
Woodward, S. L.; Waghorn G. C.; Ulyatt M. J.; Lassey K. R. (2001) Early indications that feeding Lotus will reduce methane emission from ruminants. Proc. N.Z. Anim. Prod., 61, 23-26

Woodward, S.L.; Waghorn, G.C. \& Thomson, N.A. (2006) Supplementing dairy cows with oils to improve performance and reduce methane - does it work? Proceedings of the New Zealand Society of Animal Production, 66, 176-181

Woodward, S.L.; Waghorn, G.C.; Lassey, K.R.; Laboyrie, P.G. (2002) Does feeding sulla (Hedysarum coronarium) reduce methane emission from dairy cows? Proc. N. Z. Soc. Anim. Prod., 62, 227-230

Woolcock, J.P. (1991) Microbiology of animals and animal products. Elsevier Scientific Publishers B.V.

Wright, A.D.; Auckland, C.H.; Lynn, D.H. (2007) Molecular diversity of methanogens in feedlot cattle from Ontario and Prince Edward Island, Canada. Appl. Environ. Microbiol., 73, 4206-4210

Wuebbles, D.J.; Hayhoe, K. (2001) Atmospheric methane and global change. Earth-Sci. Rev., $57,177-210$

Yabuuchi, Y.; Matsushita, Y.; Otsuka, H.; Fukamachi, K.; Kobayashi, Y. (2006) Effects of supplemental lauric acid-rich oils in high-grain diet on in vitro rumen fermentation. Anim. Sci. J., 77, 300-307

Zhang, C.M.; Guo, Y.Q., Yuan, Z.P.; Wu, Y.M.; Wang, J.K.; Liu, J.X.; Zhu, W.Y. (2008) Effect of octadeca carbon fatty acids on microbial fermentation, methanogenesis and microbial flora in vitro. Anim. Feed Sci. Technol., 146, 259-269

Zhu, W.Y.; Mao, S.Y.; Liu, J.X.; Cheng, Y.F.; Iqbal, M.F.; Wang, J.K. (2007) Diversity of methanogens and their interactions with other microorganisms in methanogenesis in the rumen. The Proceedings of the VII International Symposium on the Nutrition of Herbivores. China Agric. Univ. Press, 17-22

Zmora, P., Cieślak, A., Jędrejek, D., Stochmal, A., Pers-Kamczyc, E., Oleszek, W., Nowak, A., Szczechowiak, J., Lechniak, D., Szumacher-Strabel, M. (2012) Preliminary in vitro study on the effect of xanthohumol on rumen methanogenesis. Arch. Anim. Nutr., $66,66-71$ 


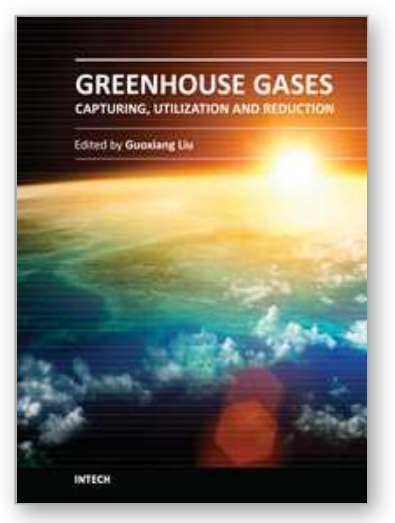

\author{
Greenhouse Gases - Capturing, Utilization and Reduction \\ Edited by Dr Guoxiang Liu
}

ISBN 978-953-51-0192-5

Hard cover, 338 pages

Publisher InTech

Published online 09, March, 2012

Published in print edition March, 2012

Understanding greenhouse gas capture, utilization, reduction, and storage is essential for solving issues such as global warming and climate change that result from greenhouse gas. Taking advantage of the authors' experience in greenhouse gases, this book discusses an overview of recently developed techniques, methods, and strategies: - Novel techniques and methods on greenhouse gas capture by physical adsorption and separation, chemical structural reconstruction, and biological utilization. - Systemic discussions on greenhouse gas reduction by policy conduction, mitigation strategies, and alternative energy sources. - A comprehensive review of geological storage monitoring technologies.

\title{
How to reference
}

In order to correctly reference this scholarly work, feel free to copy and paste the following:

Małgorzata Szumacher-Strabel and Adam Cieślak (2012). Dietary Possibilities to Mitigate Rumen Methane and Ammonia Production, Greenhouse Gases - Capturing, Utilization and Reduction, Dr Guoxiang Liu (Ed.), ISBN: 978-953-51-0192-5, InTech, Available from: http://www.intechopen.com/books/greenhouse-gases-capturingutilization-and-reduction/dietary-possibilities-to-mitigate-rumen-methane-and-ammonia-production

\section{INTECH}

open science | open minds

\section{InTech Europe}

University Campus STeP Ri

Slavka Krautzeka 83/A

51000 Rijeka, Croatia

Phone: +385 (51) 770447

Fax: +385 (51) 686166

www.intechopen.com

\section{InTech China}

Unit 405, Office Block, Hotel Equatorial Shanghai

No.65, Yan An Road (West), Shanghai, 200040, China

中国上海市延安西路65号上海国际贵都大饭店办公楼405单元

Phone: +86-21-62489820

Fax: +86-21-62489821 
(C) 2012 The Author(s). Licensee IntechOpen. This is an open access article distributed under the terms of the Creative Commons Attribution 3.0 License, which permits unrestricted use, distribution, and reproduction in any medium, provided the original work is properly cited. 